\title{
Planetary habitability: lessons learned from terrestrial analogues
}

\author{
Louisa J. Preston' and Lewis R. Dartnell ${ }^{2}$ \\ ${ }^{1}$ Department of Physical Sciences, The Open University, Milton Keynes MK7 6AA, UK \\ e-mail:louisa.preston@open.ac.uk \\ ${ }^{2}$ Space Research Centre, University of Leicester, Leicester LE1 7RH, UK
}

\begin{abstract}
Terrestrial analogue studies underpin almost all planetary missions and their use is essential in the exploration of our Solar system and in assessing the habitability of other worlds. Their value relies on the similarity of the analogue to its target, either in terms of their mineralogical or geochemical context, or current physical or chemical environmental conditions. Such analogue sites offer critical ground-truthing for astrobiological studies on the habitability of different environmental parameter sets, the biological mechanisms for survival in extreme environments and the preservation potential and detectability of biosignatures. The 33 analogue sites discussed in this review have been selected on the basis of their congruence to particular extraterrestrial locations. Terrestrial field sites that have been used most often in the literature, as well as some lesser known ones which require greater study, are incorporated to inform on the astrobiological potential of Venus, Mars, Europa, Enceladus and Titan. For example, the possibility of an aerial habitable zone on Venus has been hypothesized based on studies of life at high-altitudes in the terrestrial atmosphere. We also demonstrate why many different terrestrial analogue sites are required to satisfactorily assess the habitability of the changing environmental conditions throughout Martian history, and recommend particular sites for different epochs or potential niches. Finally, habitable zones within the aqueous environments of the icy moons of Europa and Enceladus and potentially in the hydrocarbon lakes of Titan are discussed and suitable analogue sites proposed. It is clear from this review that a number of terrestrial analogue sites can be applied to multiple planetary bodies, thereby increasing their value for astrobiological exploration. For each analogue site considered here, we summarize the pertinent physiochemical environmental features they offer and critically assess the fidelity with which they emulate their intended target locale. We also outline key issues associated with the existing documentation of analogue research and the constraints this has on the efficiency of discoveries in this field. This review thus highlights the need for a global open access database for planetary analogues.

Received 16 July 2013, accepted 27 September 2013
\end{abstract}

Key words: analogue, Earth, Enceladus, Europa, Extremophile, habitability, Mars, Titan.

\section{Introduction}

Astrobiology and the search for life beyond Earth are necessarily informed by the study of environments, and organisms that reside within them, on our own planet. We grow our knowledge base of what might be considered a habitable environment on other worlds by reference to extreme terrestrial environments and the survival strategies employed by the biota indigenous to these locales; different categories of extremophile life. 'Habitability' is defined as the set of physical and chemical environmental parameters that permit the persistence of life, and these are in turn delineated by biological constraints and the survival envelope exhibited by terrestrial extremophiles (Dartnell 2011). It should also be made clear, however, that many environments that cellular life can adapt to tolerate may not be appropriate for the progression of prebiotic chemistry; extremophiles may well be irrelevant to the origin of life in the first place (Cleaves \& Chalmers 2004). Nonetheless, a major component of current astrobiology is engaged with the exploration of other planetary bodies in the Solar system and comparison of their environments, past or present, to the habitable envelope of terrestrial life, in order to determine the prospects for extraterrestrial life.

Beyond the orbital distance, a planet's habitability is affected by many astrophysical, geological and geochemical factors. In its astrobiology roadmap, NASA defined the principal habitability criteria as 'extended regions of liquid water, conditions favourable for the assembly of complex organic molecules' and arguably most important, 'energy sources to sustain metabolism'. When we apply these criteria to the Earth, we observe an atmosphere that generates a sufficient greenhouse effect to allow liquid water across the surface; an ozone layer that provides protection from solar ultraviolet radiation; a global magnetic field to protect the atmosphere from the solar wind and provide shielding from cosmic radiation; and a planetary mass that can maintain plate tectonics (e.g. Kasting et al. 1993), which are all crucial for the long-term maintenance of life. An accessible liquid medium is deemed essential for life as terrestrial organisms are intricately linked to liquid water. However, fluids other than water might 


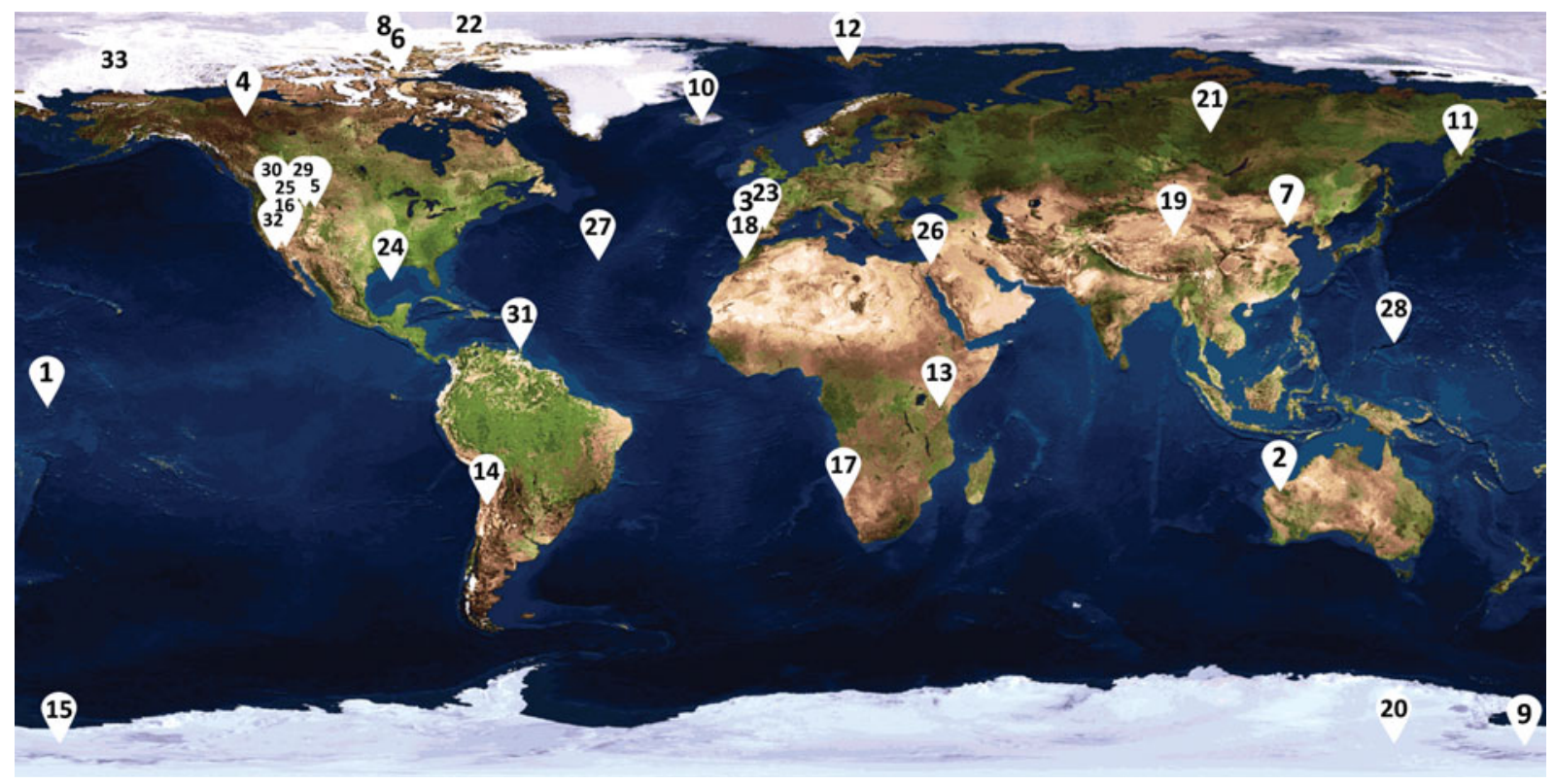

Fig. 1. Global map of the Earth with 33 analogue sites identified. All sites are described in Tables 1-3. Site 1 broadly corresponds to high-altitude atmospheric analogues for Venus.

be found on other planetary bodies therefore leading to an environment in which non-terrestrial biochemistries could evolve (e.g. Bains 2004). We have not observed such non-water biochemistries at present so our current search for extraterrestrial habitable environments favours those that would support terrestrial biochemistry.

\section{Terrestrial analogues}

Specific locations on Earth that are similar in some important respects to extraterrestrial locales, such as the Martian surface or Europan ocean, are used as field-sites for explorationrelated activities, and are known as 'analogue sites' (Fig. 1). Not only do such analogue environments inform researchers on habitability, but also the potential for the long-term preservation of signs of past life, and thus guide the selection of which potential biosignatures to target and the most appropriate analytical methods. A third function offered by terrestrial analogues is in the field-testing and in situ validation of biosignature detection instrumentation or even testing the navigation or manoeuvrability and traction of rover designs on representative terrains.

Terrestrial planets and moons composed predominantly of silicate rocks with the potential for supporting complex organic chemistry are a primary focus of astrobiological research. Through studying diverse environments on Earth we know that once life originates, it has the ability to adapt to a range of extreme environmental conditions that might previously have been deemed unsuitable. Prokaryotic and eukaryotic life on Earth can exist over an extraordinary range of $\mathrm{pH}$, temperature, pressure, salinity and radiation levels (Rothschild \& Mancinelli 2001). This observation combined with analogue research guides our assessment of the habitability of other planetary bodies and as such has considerably widened the number of potential habitable environments that could be explored on other terrestrial worlds. Analogue studies therefore now underpin almost all planetary exploration missions and are an essential first step in the search for habitable environments in the Solar system. Exploration of these areas allows comparisons and conclusions to be made regarding extraterrestrial observations of materials and features, and hypotheses formed regarding their origins and evolution. These include environmental, mineralogical, geomorphological, geochemical and biological conditions that resemble those found at present or at some point in the past on another planetary body. While each individual analogue site is not a perfect representation of the changing conditions through time of another world, the combination of analogue research with laboratory simulations and data obtained from orbiters and landers allows steps to be taken to advance our knowledge (Léveillé 2010).

At present, terrestrial analogue studies are the best way for us to study the habitability potential of other planets and moons, and to help us design and develop tools and technologies for their exploration. That said, they have their limitations, no analogue site is a perfect representation of another planet or moon and there are no clearly defined and followed criteria with which to evaluate them. Soare et al. (2001) attempted to redress this with a three-tiered model which in this review we apply specifically to habitability.

The first tier or 'analogues of the first order' are based upon direct, empirical evidence. For example, we have data and images to certify that Mars has volcanoes, is composed of volcanic rocks, is covered in impact craters and has ice caps, all possible sites for habitable niches. This means that volcanoes, basalts, impact craters and ice-covered environments on Earth are analogues of the first-order albeit never perfect given the drastically different environment of both planets. 
'Analogues of the second order' are based on indirect or highly suggestive evidence that is awaiting data to provide confirmation. Research into the conditions and biota within Lake Vostok is an example of an analogue of the second order as it is used to assist studies into the habitability potential of a brine ocean on Europa for which there is abundant indirect evidence supporting its presence (e.g. Kargel et al. 2000; Pappalardo 2010; Keszthelyi 2011) and its possible composition. Another example, especially relevant for the search for habitable environments on Mars, is the lack of observed liquid water on its surface. Evidence of past water action is present as landforms that look like artefacts of fluvial action (e.g. Malin \& Edgett 2000) and to some extent even mineral deposits that require water for their formation. While the connection between these features and water seems plausible or even undeniable, direct evidence for running water is still elusive. Studying analogues for these features, however, is important; they are simply second-order observations that have the potential to be proven false. Analogues of the third order are those that are not sustained by direct or indirect target evidence. There is no direct or indirect evidence that life exists anywhere other than on Earth; however, terrestrial analogues for this life are incredibly important and are integral to the development of scenarios for planetary habitability. Extremophiles are, therefore, an example of third-order analogues.

The purpose of this review is not to provide an exhaustive list of all terrestrial analogue sites that have been used to study the habitability potential of Venus, Mars and the outer icy moons. Instead, its aim is to evaluate the number and scope of key sites that are contributing most to our understanding of potential extraterrestrial habitable environments in the Solar system, and to assess our ability to access and utilize the information. Through this review of these analogue sites we are able to better understand: (1) the processes that have led to a habitable environment, or the loss of one, on Earth and other planetary bodies; (2) the diversity of environments that can inform our knowledge about multiple locations in the Solar system; (3) the potential for life, its preservation and identification over geological time; and (4) identify where research is being duplicated, where there are gaps in our knowledge of certain sites and what new analogue sites are needed. The analogue sites covered in this review are shown on the map in Fig. 1 and are numerically correlated to the analogues sites listed in Tables 1-3.

\section{Terrestrial planets}

\section{Venus}

Venus has the highest surface temperature of any planet in the Solar system, due to its proximity to the Sun and the powerful greenhouse effect produced by its thick 90 bar atmosphere of $>96 \% \mathrm{CO}_{2}$. Venus is at the inner edge of the stellar $\mathrm{HZ}$ and has undergone a runaway greenhouse effect (Walker 1975; Kasting 1988) that vaporized any past oceans (Hasimoto et al. 2008). The surface temperature is around $460^{\circ} \mathrm{C}$, preventing the possibility of liquid water or even stable organic molecules (although the possibility of supercritical water in the subsurface has been discussed by Schulze-Makuch \& Irwin 2002). The Venusian surface, therefore, is not a habitable environment for life as we know it, at least not today, and as such there are limited analogue sites that exist on Earth.

High above the surface, however, there is a potential habitable zone where temperatures lie in the range between freezing and $120^{\circ} \mathrm{C}$ and liquid water is available. The lower and middle cloud deck within this high-altitude habitable region may therefore support an aerial biosphere (Cockell 1999). These clouds offer long-lasting droplets of water, although they are highly acidic with dissolved $\mathrm{H}_{2} \mathrm{SO}_{4}$, and metabolic energy sources are available through sulphate reduction (Cockell 1999) or photosynthesis (Schulze-Makuch et al. 2004). Hyperthermophilic acidophiles found in hot acidic waters, such as Acidianus infernus (Segerer et al. 1986), which exhibit optimal growth at $88^{\circ} \mathrm{C}$ and in acidic conditions as low as $\mathrm{pH} 0.5$ are therefore key analogue organisms for Venus.

While analogue sites on Earth do not offer long-lived aerosols with comparable temperatures or acidities, the presence of life at high altitudes in the terrestrial atmosphere is well-known (Rothschild \& Mancinelli 2001). Womack et al. (2010) summarizes the argument that the atmosphere represents a genuine niche for micro-organisms rather than simply a transient transport phase between terrestrial surface locations. Evidence shows that bacteria may be actively metabolizing in clouds above the Earth driving biogeochemical cycling, as well as reproducing. The limiting factor on a terrestrial aerial biosphere is likely to not be nutrient availability or environmental extremes, but residence time in the atmosphere before precipitating back down (see review in Womack et al. 2010).

Unlike the surface-based analogue sites discussed elsewhere in this review, the exact locations for Venusian atmospheric analogue habitable environments are transient and simply require access to the high-altitude atmosphere. For example, Sattler et al. (2001) demonstrate growth of bacteria in super cooled cloud droplets sampled from a meteorological station on a mountain top in the Alps, whereas Temkiv et al. (2012) used hail stone fall as a natural contamination-proof means for sampling within storm clouds. Viable bacteria have also been found at much greater altitudes, beyond the tropopause boundary in the stratosphere, through sampling by stratospheric balloon flight (Harris et al. 2001; Wainwright et al. 2003) and high-altitude research aircraft (Smith et al. 2010). As we learn more about the limits to life and the conditions that might have existed on Venus in the past and are present today in the clouds, there is a growing need for more terrestrial analogue sites to inform understanding of how life might be able to tolerate the potential Venusian atmospheric niche; in particular acidic and nutrient-poor conditions, and permanent residence within aerosolized droplets.

\section{Mars}

In many respects, Mars is the most Earth-like planet in the Solar system and is believed to have once provided a much warmer and wetter environment: habitable conditions for the 
Table 1. Selected analogue sites for Mars

\begin{tabular}{lll}
\hline Location & Features & Selected publications
\end{tabular}

\section{Early Mars}

(2) The Pilbara Region, West Australia

(3) Rio Tinto, SW Spain

(4) The Golden Deposit, Canadian High Arctic

(5) Yellowstone National Park, USA

(6) Haughton Impact Structure, Devon Island

(7) Dongwanzi Ophiolite Complex, China

\section{Middle Mars}

(8) Axel Heiberg Island, Canadian High Arctic

(9) Beacon Valley, Antarctica

(10) Sub-glacial Volcanism, Iceland

(11) Kamchatka, Russian Federation
- Undeformed Archaean 3.5-2.7 Ga, volcanic rocks

- North Pole Dome hydrothermal activity

- Abundant phyllosilicates within basaltic lavas

- Stromatolites and putative microfossils $>3$ Ga old

- Analogue for flood basalts; water-related alteration minerals; preservation of early life

- Natural acid rock drainage system

- pH 3.2 and precipitates of iron sulphates and oxides

- Chemolithotrophic community dominated by iron oxidizing acid tolerant bacteria

- 2 Ma iron oxide and sulphate-rich river terraces with microbial fossils

- Analogue for past river channels; iron oxides and sulphates; preservation of life; acidophiles

- Cold, acidic ( $\mathrm{pH}$ 3) springs precipitating jarosite and natrojarosite

- Permafrost environment

- Microbial filaments, sulphate reducing bacteria.

- Analogue for mineralogy and water chemistry at Meridiani Planum and Mawrth Vallis; extremophiles

- Over 300 springs, e.g. Grand Prismatic and Chocolate Pots

- Silica sinters, opaline-rich soils, iron deposits and microbial mats

- Chemotrophic and phototrophic micro-organisms

- Microfossils and stromatolites, permineralization

- Analogue for silica-rich soils; hydrothermal activity; preservation of ancient life; thermophiles

- 39 Ma old Arctic impact structure

- Supported a $14 \mathrm{~km}$ diameter crater lake and hydrothermal system

- Hydrothermal gypsum contains cyanobacterial endolithic communities

- Analogue for impact craters; crater lake deposits and hydrothermal alteration; habitats for and preservation of life; extremophiles

- Archaean ophiolite complex

- Mafic and ultramafic rocks, water-rock-biology interactions

- Bio-alteration on volcanic rocks

- Analogue for martian crustal rocks and Mars meteorites; chemolithoautotrophic biospheres

- Polar desert with ground ice and permafrost

- Over 40 perennial saline springs and seeps, e.g. Gypsum Hill and Colour Peak

- Chemosynthetic communities - sulphur-metabolizing bacteria

- Analogue for liquid water in cold environments on Mars; spring mineral deposits; extremophiles

- Dry Valley, 8-10 Ma old ice deposits

- Psychrophilic microbial communities - active and fossil

- Life preserved within glacial ice

- Cryoconites

- Analogue for Polar Layered Deposits and Northern High latitude regions on Mars; life active and preserved in ice deposits; extremophiles

- Most volcanism on Iceland has direct interactions with glacial activity

- Volcano-ice interactions generating liquid water.

- Psycrotolerant and chemotrophic bacteria

- Meltwater caves, lakes fumaroles, hot springs, mineral deposits present

- Analogue for the creation of habitable environments on Mars; geothermal features and mineral deposits; caves; volcanoes; preservation of life; extremophiles

- Volcanic belt of 160 volcanoes, 29 still active.

- Geyser Valley of hot springs and geothermal features

- Thermophiles and psychrophiles

- Glacial and periglacial landforms

- Analogue for volcanic landforms; volcano-ice interactions; geothermal features; gullies; extremophiles
(Walter et al. 1980;

Allwood et al. 2006;

Brown et al. 2006;

Van Kranendonk et al. 2008;

Westall 2008)

(Gónzález-Toril et al. 1999, 2003;

Fernández-Remolar et al. 2005;

Amils et al. 2007; Preston et al. 2011)

(Michel 1977; Battler et al. 2012)

(Parenteau \& Cady 2010; Ruff et al. 2011)

(Grieve 1988; Osinski et al. 2001;

Cockell \& Lee 2002;

Cockell et al. 2002;

Parnell et al. 2004;

Osinski \& Lee 2005;

Osinski et al. 2005)

Kusky et al. (2001)

(Pollard et al. 1999;

Heldmann et al. 2000;

Andersen et al. 2002;

Perreault et al. 2007; 2008;

Pollard et al. 2009)

(Abyzov 1993; Sugden et al. 1995; Psenner 1999; Horneck 2000;

Miteva et al. 2004;

Storrie-Lombardi \& Sattler 2009; Heldmann et al. 2013)

(Boston et al. 1992;

Gudmundsson et al. 1997;

Bourgeois et al. 1998;

Chapman et al. 2000;

Preston et al. 2008;

Herrera et al. 2009;

Cousins \& Crawford 2011)

(Demidov \& Gilichinsky 2009;

Souness \& Abramov 2012) 
Table 1. (Cont.)

\begin{tabular}{|c|c|c|}
\hline Location & Features & Selected publications \\
\hline $\begin{array}{l}\text { (12) Bockfjord Volcanic } \\
\text { Complex, Svalbard }\end{array}$ & $\begin{array}{l}\text { - Three eruptive centres over } 20 \mathrm{~km} \text { with volcanic and subvolcanic } \\
\text { features } \\
\text { - Volcanic soils and flood basalts in an arctic glacial environment } \\
\text { - Carbonate rosettes as observed in the ALH84001 meteorite } \\
\text { - Methanogens, psychrophiles and microbial activity within blue ice } \\
\text { - Analogue for carbonates; polar habitats; fluvial features; gullies; } \\
\text { volcanoes; hot springs; biosignatures; extremophiles }\end{array}$ & $\begin{array}{l}\text { (Steele } \text { et al. 2006, 2007, 2008; } \\
\text { Hauber } \text { et al. 2009) }\end{array}$ \\
\hline $\begin{array}{l}\text { (13) Kilimanjaro, Tanzania, } \\
\text { Africa }\end{array}$ & $\begin{array}{l}\text { - Stratovolcano with high elevation, periglacial environment } \\
\text { - Volcanic Fe, Al-silicate soils with extremophilic micro-organisms } \\
\text { - High UV flux, low atmospheric pressure, low water and nutrient } \\
\text { availability } \\
\text { - Fumaroles, fissure vents, glaciers and meltwater ponds } \\
\text { - Analogue for habitability in oligotrophic volcanic mineral soils and ices; } \\
\text { microbial habitability in fumaroles and melting glaciers across } \\
\text { temperature and water gradients; extremophiles }\end{array}$ & (Ponce et al. 2011a, b) \\
\hline \multicolumn{3}{|l|}{ Present Mars } \\
\hline $\begin{array}{l}\text { (14) The Atacama Desert, } \\
\text { South America }\end{array}$ & $\begin{array}{l}\text { - One of the driest regions on Earth, }<2 \mathrm{~mm} \text { precipitation per year } \\
\text { - Perchlorate-rich volcanic soils } \\
\text { - Low levels of bacteria and organic materials within soils } \\
\text { - Endolithic photosynthetic microbes within halite crusts and pore spaces } \\
\text { - Analogue for 'Mars-like soils' and perchlorates; volcanics; playas; } \\
\text { impact deposits; Endoliths; extremophiles; UV radiation and aridity }\end{array}$ & $\begin{array}{l}\text { (Navarro-González et al. 2003; } \\
\text { Warren-Rhodes } \text { et al. 2006; } \\
\text { Wierzchos } \text { et al. } 2006 ; \text { Cabrol } \text { et al. } \\
\text { 2007; Connon } \text { et al. 2007; } \\
\text { Ewing } \text { et al. 2008; } \\
\text { Valdiva-Silva } \text { et al. 2011, 2012) }\end{array}$ \\
\hline $\begin{array}{l}\text { (15) The Antarctic Dry } \\
\text { Valleys, Antarctica }\end{array}$ & $\begin{array}{l}\text { - One of the coldest and driest regions on Earth - extreme environment } \\
\text { - Closest terrestrial analogue to Mars } \\
\text { - Highest UV-B irradiance levels on Earth } \\
\text { - Photosynthetic micro-organisms, autotrophic bacteria and fungi } \\
\text { (cryptoendoliths) } \\
\text { - Analogue for Martian cold and dry deserts; gullies; extremophiles; } \\
\text { extreme survival and space mission simulations }\end{array}$ & $\begin{array}{l}\text { (Friedmann } 1980 ; \\
\text { Wyn-Williams \& Edwards } 2000 ; \\
\text { Onofri et al. 2004; Gilichinsky et al. } \\
2007 \text {; } \\
\text { Doran et al. 2012) }\end{array}$ \\
\hline (16) The Mojave Desert, USA & $\begin{array}{l}\text { - Dry region }<6 \mathrm{~cm} \text { year }{ }^{-1} \text { recorded in Death Valley } \\
\text { - Volcanic geology } \\
\text { - Soil-based microbial activity } \\
\text { - Desert varnish and the preservation of organic molecules } \\
\text { - Analogue for physical and chemical processes on an arid Mars; } \\
\text { volcanics; desert varnish; preservation of life; extremophiles within soils }\end{array}$ & $\begin{array}{l}\text { (Greeley et al. 2002; Perry et al. 2003, } \\
\text { 2006; Bryant \& Rech 2008) }\end{array}$ \\
\hline $\begin{array}{l}\text { (17) The Namib Desert, } \\
\text { Namibia, Africa }\end{array}$ & $\begin{array}{l}\text { - Oldest desert on Earth } \\
\text { - Dune seas, rocky plains and dry river oases } \\
\text { - Most rivers flow underground or are dry most of the year } \\
\text { - Life present living with limited water availability and high temperatures } \\
\text { - Analogue for Mars deserts; large dunes; aeolian features; extremophiles }\end{array}$ & $\begin{array}{l}\text { (Bourke } \text { et al. 2004; } \\
\text { Bourke \& Goudie 2009; Bourke 2010) }\end{array}$ \\
\hline $\begin{array}{l}\text { (18) Ibn Battuta Centre Sites, } \\
\text { Morocco }\end{array}$ & $\begin{array}{l}\text { - Five main analogue site areas } \\
\text { - Arid desert environment, flood basalts and carbonates present } \\
\text { - Seafloor mud mounds and preserved microbial populations } \\
\text { - Fossil and active extremophilic life in a range of environments } \\
\text { - Analogue for ancient stromatolites; modern bacteria; mud volcanoes; } \\
\text { travertine; evaporites; fossil geothermal systems; clays and basalts }\end{array}$ & $\begin{array}{l}\text { Cavalazzi et al. (2007); The Ibn } \\
\text { Battuta Centre website: http://www. } \\
\text { ibnbattutacentre.org/ }\end{array}$ \\
\hline $\begin{array}{l}\text { (19) Qaidam Basin, Tibetan } \\
\text { Plateau }\end{array}$ & $\begin{array}{l}\text { - Cold hyper arid basin with extant and desiccated evaporative lakes } \\
\text { - High elevation }(4500 \mathrm{~m}) \text {, solar UV and diurnal temperature variations } \\
\text { - Sulphate-rich mineralogy } \\
\text { - Halophiles and halobacteria within salts } \\
\text { - Analogue for sulphates on Mars; saline playas; extremophiles }\end{array}$ & (Mayer et al. 2009; Wang et al. 2010) \\
\hline
\end{tabular}

emergence and persistence of life. This planetary similarity is reflected in the number and diversity of Martian analogue sites available for study on Earth. Mars, however, has undergone global environmental change in its past (shown in Fig. 2), and so various terrestrial analogue sites are taken not just as emulations of the conditions prevalent in different regions on Mars, but also at different points in its evolutionary history. One of the main steps in assessing habitability on Mars is the evidence of past or present water. The selected analogue sites listed in Table 1 are, therefore, organized into rough epochs of Early Mars (Fig. 3), Middle Mars (Fig. 4) and Present Mars (Fig. 5), and focus on the evolving climate of Mars and the habitable analogues that can be applied. The sites listed in this table have been selected not only to include areas that are highly utilized and so have been well-characterized, but also highlight those less well-known areas that hold valuable information and require greater study to guide our understanding of the range of habitable environments possible 
Table 2. Selected Analogue Sites for Europa and Enceladus

\begin{tabular}{|c|c|}
\hline Location & Features \\
\hline \multicolumn{2}{|l|}{ Surface Ice } \\
\hline $\begin{array}{l}\text { (20) Lake Vostok, } \\
\text { Antarctica * }\end{array}$ & $\begin{array}{l}\text { - One of more than } 387 \text { subglacial lakes under Antarctica including } \\
\text { Lakes Bonney, Vida and Ellsworth } \\
\text { - Located } 4 \mathrm{~km} \text { beneath the East Antarctic ice sheet } \\
\text { - Remained at least partially isolated for at least } 14 \mathrm{Ma} \\
\text { - Any life here would be adapted to extreme darkness, low nutrient } \\
\text { levels, high water pressures and isolation from the atmosphere } \\
\text { - Analogue for ice sheet-ocean interface; hydrostatic pressure at base of } \\
\text { the Europan ice sheet; preservation of biosignatures within ice; } \\
\text { polyextremophiles }\end{array}$ \\
\hline $\begin{array}{l}\text { (21) Permafrost, } \\
\text { Multiple Sites }\end{array}$ & $\begin{array}{l}\text { - Underlies } 20 \% \text { of the Earth's land surfaceFrozen sediments can } \\
\text { harbour a range of viable micro-organisms } \\
\text { - Preserves ancient life for up to } 3 \mathrm{Ma} \text { old, and are still viable } \\
\text { - Analogue for the stability of ice as a preservation medium for life over } \\
\text { geological time; microbial survival and biosignatures, extremophiles }\end{array}$ \\
\hline $\begin{array}{l}\text { (22) The Borup Fiord Pass, } \\
\text { Ellesmere Island }\end{array}$ & $\begin{array}{l}\text { - Perennial subsurface alkaline spring waters } \\
\text { - Deposits of elemental sulphur, gypsum and calcite on glacial ice } \\
\text { - Microbially mediated sulphur-on-ice mineralogy } \\
\text { - Sulphur-reducing bacteria } \\
\text { - Analogue for chemical reactions on the Europan icy surface; spectral } \\
\text { signatures of a sulphur-based ecosystem; extremophiles }\end{array}$ \\
\hline
\end{tabular}

Brine Ocean

(23) Lake Tirez, Spain

(24) Orca Basin, Gulf of Mexico

(25) Mono Lake,

California, USA

(26) The Dead Sea, Israel

Ocean Floor

(27) Lost City, Mid-Atlantic Ridge
- Hyper-saline $\mathrm{Mg}, \mathrm{Na}, \mathrm{Cl}$ and sulphate-rich brines

- Prokaryotic halophiles, microbial mats and subsurface anaerobic communities

- Chlorophyta have been observed in the water column.

- Sulphates preserve biosignatures

- Analogue for non-ice material on the surface of Europa; may hold clues to habitability of the subsurface and can aid in preservation; extremophiles

- Deep-sea (2400 m) brine pool at the bottom of the Gulf of Mexico

- Created by the dissolution of evaporite salt beds

- Stable at base of the ocean as denser than seawater, high hydrostatic pressures

- Dominantly anoxic $\mathrm{Na}-\mathrm{Cl}$ brines and biogenic methane hydrate

- Analogue for potential salinity of the ocean; salinity as a growth limiting factor for life; halophiles

- Alkali soda lake dominated by $\mathrm{Na}-\mathrm{Cl}-\mathrm{CO}_{3}$ brines, lacking $\mathrm{Mg}$ and $\mathrm{Ca}$

- High pH values (9.9-10.1)

- Halo-alkaliphilic anaerobic bacteria, sulphate reducers

- Analogue for an alkaline ocean on Europa; life in anoxic, alkaline and saline environments; preservation of life; extremophiles

- Covers $800 \mathrm{~km}^{2}$ with an average depth of $340 \mathrm{~m}$

- Hypersaline environment, brine of $\mathrm{Na}-\mathrm{Mg}-\mathrm{Cl}$ with high concentrations of $\mathrm{Mg}$

- Halophiles, archaea Haloarcula marismortui and Haloferax volcanii

- Analogue for a saline ocean; extreme halophilic life

- Submarine site of active serpentinization $\sim 15 \mathrm{~km}$ west of the midAtlantic ridge

- 40-91 ${ }^{\circ} \mathrm{C} \mathrm{pH}$ 9-11 metal-poor hydrothermal fluids, enriched in $\mathrm{CH}_{4}$ and $\mathrm{H}_{2}$

- Microbial community sustained by abiotic alteration of mafic/ ultramafic rocks

- Sulphur-oxidizing, sulphate-reducing, and methane-oxidizing bacteria, as well as methane-producing and methane-oxidizing archaea are present

- Analogue for sea floor hydrothermal activity; extremophiles; abiotic production of biologically viable energy
Citations

(Ellis-Evans \& Wynn-Williams 1996;

Kapitsa et al. 1996; Jouzel et al. 1999;

Karl et al. 1999; Nadis 1999;

Priscu et al. 1999;

Vincent 1999; Price 2000;

Duxbury et al. 2001;

Review in Marion et al. 2003)

(Gilichinsky et al. 1993; Soina et al. 1995;

Stone 1999; Rivkina et al. 2000;

Hoover \& Gilichinsky 2001;

Gilichinsky 2002;

Review in Marion et al. 2003)

(Grasby et al. 2003; Gleeson et al. 2010, 2011,

2012; Lorenz et al. 2011)

(Kargel et al. 2000;

Prieto-Ballesteros et al. 2003)

(Pilcher \& Blumstein 2007; Meckler et al. 2008; Shah et al. 2013)

(Tierney 1997; Pikuta et al. 2003)

(Krumgalz 1997; Ventosa et al. 1999;

Krumgalz et al. 2000; Kis-Papo et al. 2001; Landis 2001; DasSarma 2003.)

(Kelley et al. 2001, 2005, 2007;

Brazelton et al. 2006; Amador et al. 2013) 
Table 2. (Cont.)

\begin{tabular}{lll}
\hline Location & Features & Citations \\
\hline (28) The Mariana Trench, & - The deepest ocean basin on Earth & (Yayanos 1995; Kato et al. 1998; \\
Pacific Ocean & - Pressure 1100 bars and temperatures as low as $1{ }^{\circ} \mathrm{C}$ & Abe et al. 1999; Sharma et al. 2002; \\
& - Bacteria can survive pressures up to 16800 bars & Glud et al. 2013) \\
& - Chemolithotrophs can survive in the ocean floor here & \\
& - Analogue for life under pressure; a deep and cold ocean & \\
- Located within the Beaverhead Mountains & (McCollom 1999; Chapelle et al. 2002) \\
(29) Lidy Hot Springs, & - Volcanic springs devoid of allochthonous organic carbon & \\
& - 200 m deep hydrothermal system, anoxic waters at $58.5^{\circ} \mathrm{C}$ & \\
& - Archaea, subsurface hydrogen-oxidizing methanogens & \\
& - Analogue for subsurface anoxic methanogenic life; volcanic habitats; & \\
& extremophiles & \\
(30) The Columbia & Late Miocene large igneous province formed by Yellowstone hot & Stevens \& McKinley (1995) \\
River Basalts, USA & spot & \\
& - Dominantly basalt with an estimated volume of 174000 km ${ }^{3}$ & \\
& - Deep subsurface microbial community, methanogens and auto- & \\
& trophy & \\
& - Confined aquifers of low-sulphate, low chloride bicarbonate waters, & \\
& pH 7.5-10.5 & \\
& - Analogue for deep subsurface microbial communities; extremophiles & \\
\hline
\end{tabular}

Table 3. Selected Analogue Sites for Titan

\begin{tabular}{|c|c|c|}
\hline Location & Features & Citations \\
\hline $\begin{array}{l}\text { (31) Pitch Lake, Trinidad and } \\
\text { Tobago }\end{array}$ & $\begin{array}{l}\text { - A natural asphalt lake } \\
\text { - Obligate anaerobic sulphur- and nitrite-oxidizing bacteria } \\
\text { - Archaeal methane metabolism } \\
\text { - Analogue for the habitability potential of liquid hydrocarbon lakes; extremophiles }\end{array}$ & $\begin{array}{l}\text { Schulze-Makuch et al. } \\
\text { (2011) }\end{array}$ \\
\hline $\begin{array}{l}\text { (32) Rancho La Brea Tar Pits, } \\
\text { California, USA }\end{array}$ & $\begin{array}{l}\text { - Pleistocene natural asphalt-soil seeps of recalcitrant petroleum hydrocarbons } \\
\text { - Individual seeps range from acidic to alkaline and high to low salinities } \\
\text { - Water present in water pockets and pore spaces } \\
\text { - Microbial community dominated by purple sulphur bacteria and halophilic } \\
\text { Archaea } \\
\text { - Analogue for microbial communities in natural asphalt; extremophiles; microbial } \\
\text { preservation of fossils and biosignatures }\end{array}$ & Kim \& Crowley (2007) \\
\hline (33) Alaskan Oil Fields, USA. & $\begin{array}{l}\text { - Continental petroleum reservoir } 1670 \mathrm{~m} \text { below the surface } \\
\text { - Well temperatures } 65-70^{\circ} \mathrm{C} \text { and pressures } 50-160 \mathrm{~atm} \\
\text { - Indigenous thermophilic bacteria and hyperthermophilic archaea } \\
\text { - Strictly anaerobic metabolisms } \\
\text { - Analogue for deep subsurface environments and microbial communities; life in } \\
\text { petroleum reservoirs; extremophiles }\end{array}$ & L'Haridon et al. (1995) \\
\hline
\end{tabular}

on Mars. Mars is a planetary analogue success story. Observations and investigations on Mars have driven analogue research of hundreds of sites that have focused our attention on areas of Mars we might have originally overlooked, and ultimately helped us to better understand the limits to life on Earth and its preservation over geological time.

The persistence of life on the Martian surface today seems unlikely, given the extremely cold and desiccating conditions, high UV radiation flux, and the lack of magnetospheric shielding against ionizing radiation (Dartnell et al. 2007). Localities on Earth exhibiting a subset of Mars-like conditions, however, have been shown to support thriving microbial communities (Table 1; Fig. 5). During the earliest epoch, when Mars was probably warmer with abundant surface liquid water and a global hydrological cycle (Andrews-Hanna et al. 2007; McEwen et al. 2007), the situation might have been much

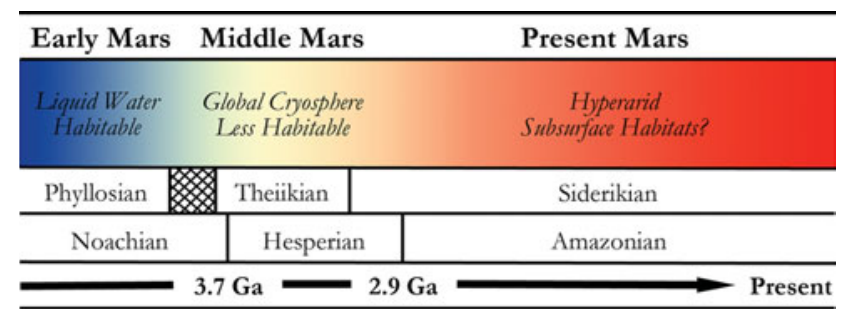

Fig. 2. Sketch of the mineralogical and climate history of Mars, with Early, Middle and Present Mars from this review included. The changing habitable conditions on the planet are also shown adapted from Bibring et al. (2006).

different. The evidence shows that 'Early Mars' had an environment similar to the Earth (Fig. 3), supporting the hypothesis that life may have had the chance to flourish 


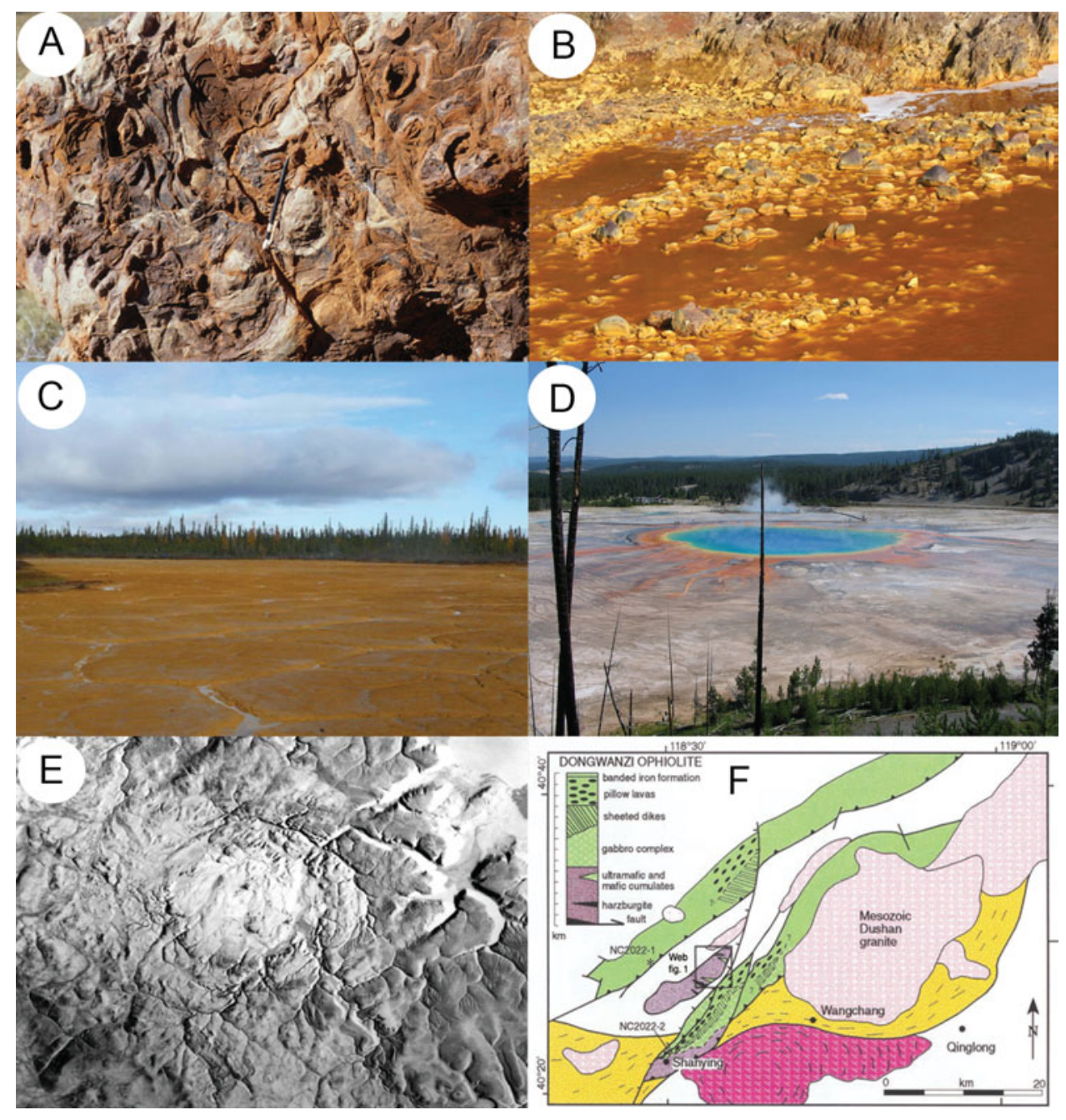

Fig. 3. Early Mars. (A) Site 2 - Stromatolites from the Pilbara Region, Western Australia (courtesy of F. Westall). (B) Site 3 - Iron-rich acidic river at Berrocal, Rio Tinto (L.J. Preston and Preston et al. 2011). (C) Site 4 - Polygons at The Golden Deposit, Canadian High Arctic (adapted from Battler et al. 2012). (D) Site 5 - Grand Prismatic Spring, Yellowstone National Park (courtesy of M. Parenteau). (E) Site 6 - Radar image of the Haughton Impact Structure, Canadian High Arctic. (F) Site 7 - Geological map of the Dongwanzi Ophiolite Complex region, China (Adapted from Kusky et al. 2001).

(Schulze-Makuch et al. 2005) as it did on Earth during this time. However, after the first few hundred million years, the environmental histories of these two planets diverged drastically. Mars underwent a global climate shift resulting in a drop in surface temperatures and loss of liquid water (e.g. Fairén et al. 2003; Bibring et al. 2006). This resulted in a global cryosphere with ice located throughout the soil, in glaciers and in the polar caps (as observed in the analogue sites within Fig. 4); and led to the creation of the Mars we observe today.

Detailed mineral compositions of Mars, obtained by landers and orbiters, have revealed that Mars presented a geochemically active environment (Gendrin et al. 2005; Bibring et al. 2007). Mineralogical surface alteration products give an insight into the conditions on the surface throughout these climatic shifts and are described in detail by Bibring et al. (2006). Three eras are proposed and shown in Fig. 2: (a) the Phyllosian era - abundant phyllosilicates created through non-acidic aqueous alteration; (b) the Theiikian era - sulphate deposits formed by acidic aqueous alteration; and (c) the Siderikian era - global ferric oxides produced through atmospheric water-free alteration. A number of analogue sites in Table 1 have been selected to represent these eras.

Mars has transitioned through three climatic stages: from relatively wet to semi-arid to hyper-arid conditions, and consequently the surface habitability has deteriorated greatly over its planetary history (Fig. 2). Analogues for habitability during these time frames are, therefore, required to mimic the geological and as far as possible the environmental conditions present, as well as the microorganisms that could survive in these places. These provide valuable insights into the range of habitable environments possible on Mars in the primordial past, at present, and as the conditions deteriorated; and how life could have survived and adapted as it is found to do in extreme environments on Earth. 


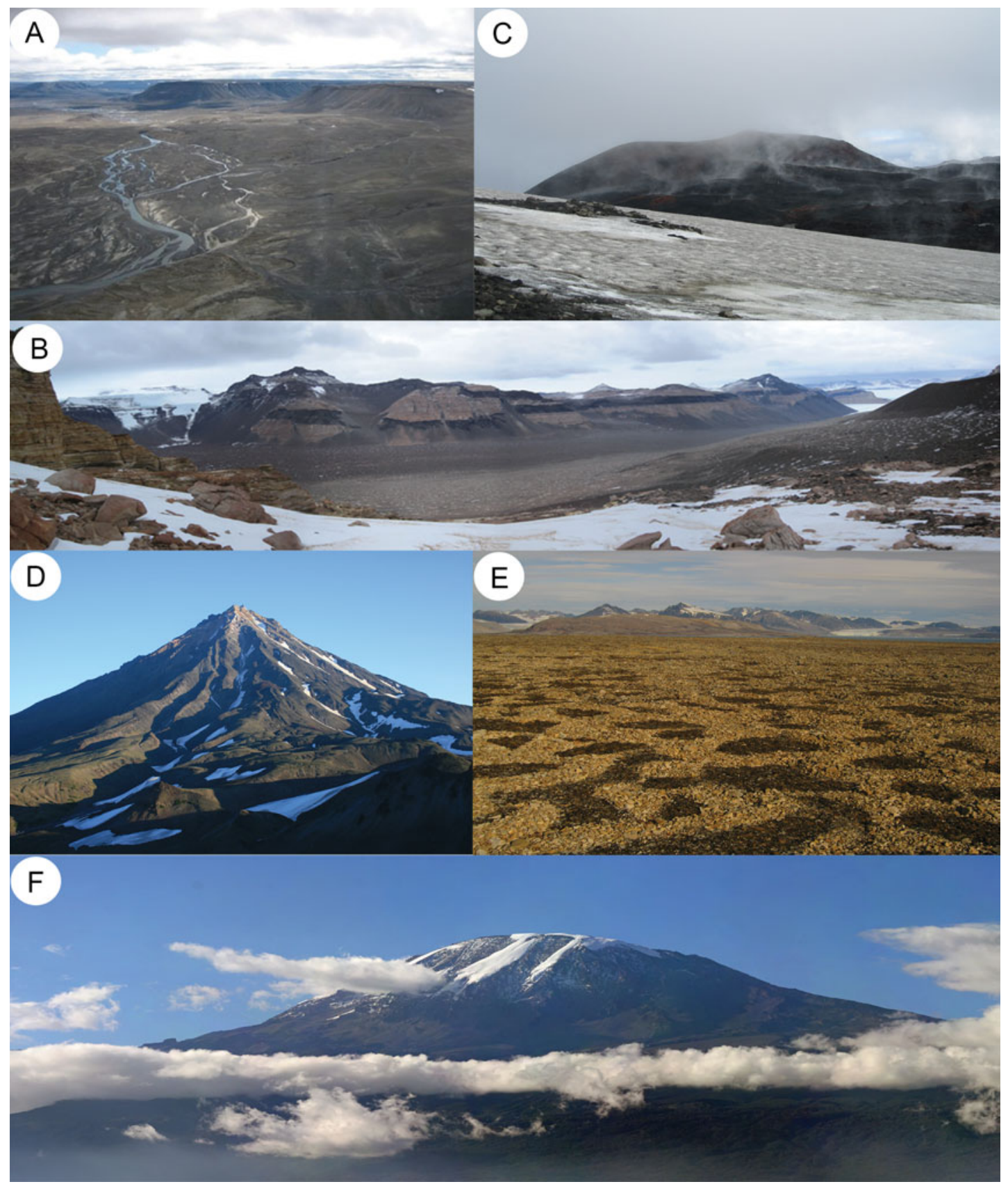

Fig. 4. Middle Mars. (A) Site 8 - Drainage patterns at Axel Heiberg Island, Canadian High Arctic (courtesy of A. Singleton). (B) Site 9 - Beacon Valley, Dry Valleys, East Antarctica (adapted from Fairén et al. 2010). (C) Site 10 - Fimmvörðuháls volcanic crater and lava field, Iceland (L.J. Preston). (D) Site 11 - Koriaksky volcano, Kamchatka, Russian Federation (courtesy of C. Souness). (E) Site 12 - View of the Bockfjord Volcanic Complex, Svalbard (courtesy of C.Cousins/Arctic Mars Analog Svalbard Expedition 2010). (F) Site 13 - Mount Kilimanjaro, Tanzania (Credit: Muhammad Mahdi Karim).

\section{Icy moons}

The terrestrial planets do not present very habitable conditions on their surfaces today, but Mars may contain preserved biosignatures within surface materials, or active communities deep in the subsurface, and Venus may offer habitable conditions high in the atmosphere. As such, the traditional formulation of the habitable zone around a star is perhaps too restrictive, especially when we consider the potential for habitable environments on terrestrial planets other than Earth, and subsurface aqueous environments within the icy moons of the gas giant planets, physically located far beyond the proposed habitable zone and thawed by a heat budget provided not by insolation but tidal heating (e.g. Sotin et al. 2002; Roberts \& Nimmo 2008).

Some of the most important astrobiological targets in the Solar system are found on moons. The most promising icy satellites of Jupiter and Saturn, namely Europa, Enceladus and 


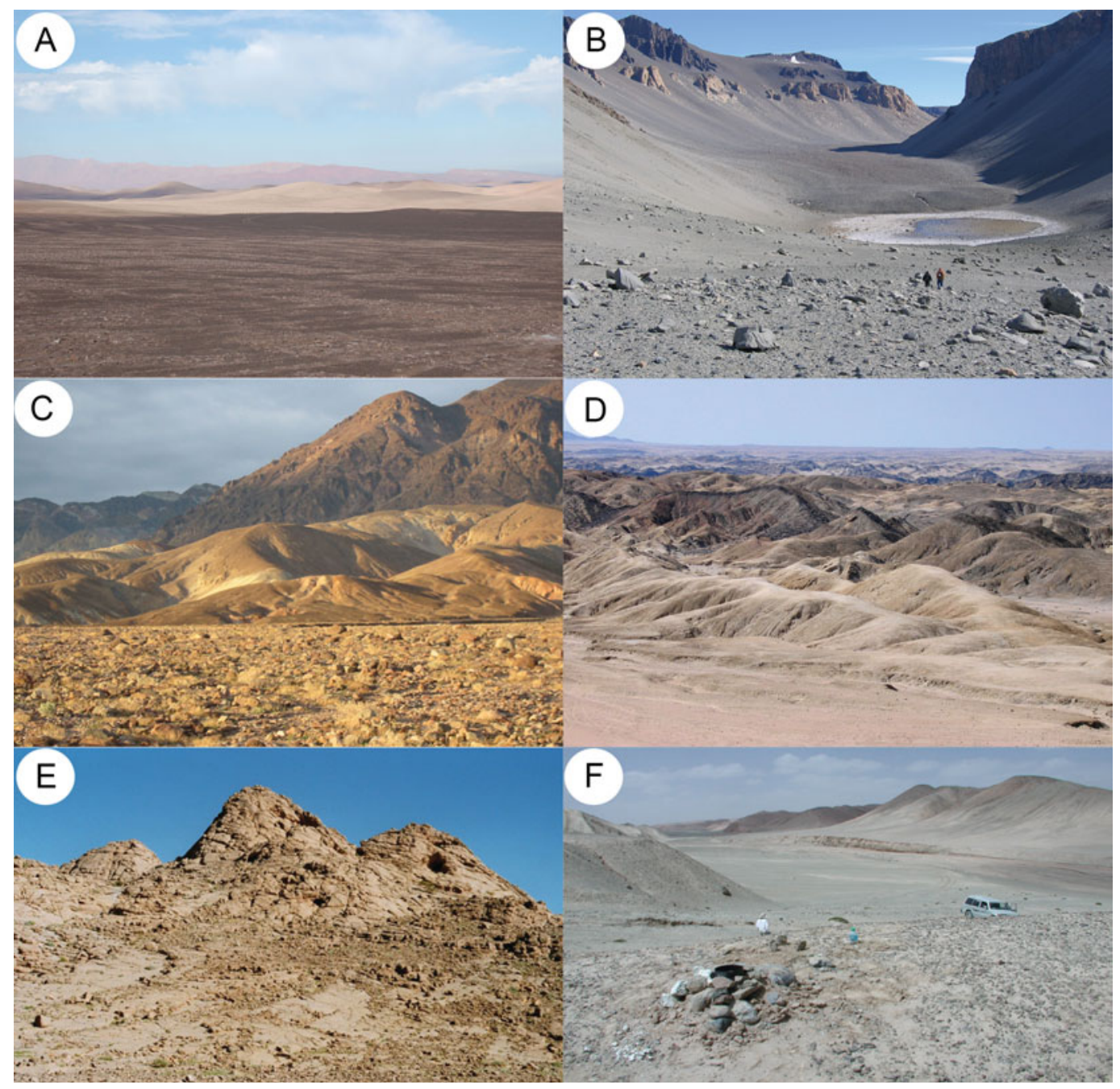

Fig. 5. Present Mars. (A) Site 14 - The desert environment of the Atacama, South America (courtesy of J. DiRuggiero). (B) Site 15 - The Antarctic Dry Valleys, Antarctica (courtesy of M. McLeod). (C) Site 16 - The Mojave Desert, USA. (D) Site 17 - Landscape of the Moon, Namib Desert, Africa (Credit: Harald Süffle, CC-BY-SA-2.5). (E) Site 18 - The Kess Kess carbonate mounds near the Ibn Battuta Centre, Morocco (Credit: Andres Rueggeberg). (F) Site 19 - The hyperarid Qaidam Basin, Tibetan Plateau (Credit: NASA/Ames).

Titan, have been revealed by recent space missions to be geologically active bodies hosting a wealth of potentially habitable environments. The problem for astrobiological ground-truthing, however, is that the environments on these moons are so extreme compared with those on Earth that suitable terrestrial analogues are fewer in number, and our knowledge of the conditions actually present on the Ice moons are mainly based on inferences, rather than definitive data.

\section{Europa}

Europa is constantly bombarded with ionizing radiation (Baumstark-Khan \& Facius 2002) as it lies within Jupiter's magnetosphere and temperatures at the surface range from 86 to $132 \mathrm{~K}$ ( -187 to $-141{ }^{\circ} \mathrm{C}$ ) (Spencer et al. 1999) far below the lowest limits for microbial growth. As such the ice itself is not a habitable environment that any currently known terrestrial life could withstand, however, the ice could provide enough protection from the radiation to allow preservation of organics and any life forms within it (Gilichinsky et al. 1993;
Hoover \& Gilichinsky 2001; Gilichinsky 2002). The low temperatures will preclude biological activity anywhere near the Europan surface but perhaps near the base of the ice layer at the interface with an ocean below, temperatures might prove to be more favourable. A number of ice-dominated habitats on Earth could provide analogues for habitable niches here (Fig. 6).

There is abundant indirect evidence supporting the presence of a brine ocean beneath the ice of Europa (Kargel et al. 2000; Pappalardo 2010) and suggestions that its composition consists of hydrated minerals (Carlson et al. 1999; McCord et al. 1999); but whether these are sulphate salts, acid or alkaline conditions remains unknown. This putative ocean has been the focus of much attention surrounding possible habitable environments (e.g. Reynolds et al. 1983; Jakosky \& Shock 1998; Gaidos et al. 1999; McCollom 1999; Chyba 2000; Kargel et al. 2000; Chyba \& Hand 2001; Chyba \& Phillips 2001; Navarro-Gonzalez et al. 2002; Pierazzo \& Chyba 2002; Schulze-Makuch \& Irwin 2002; Marion et al. 

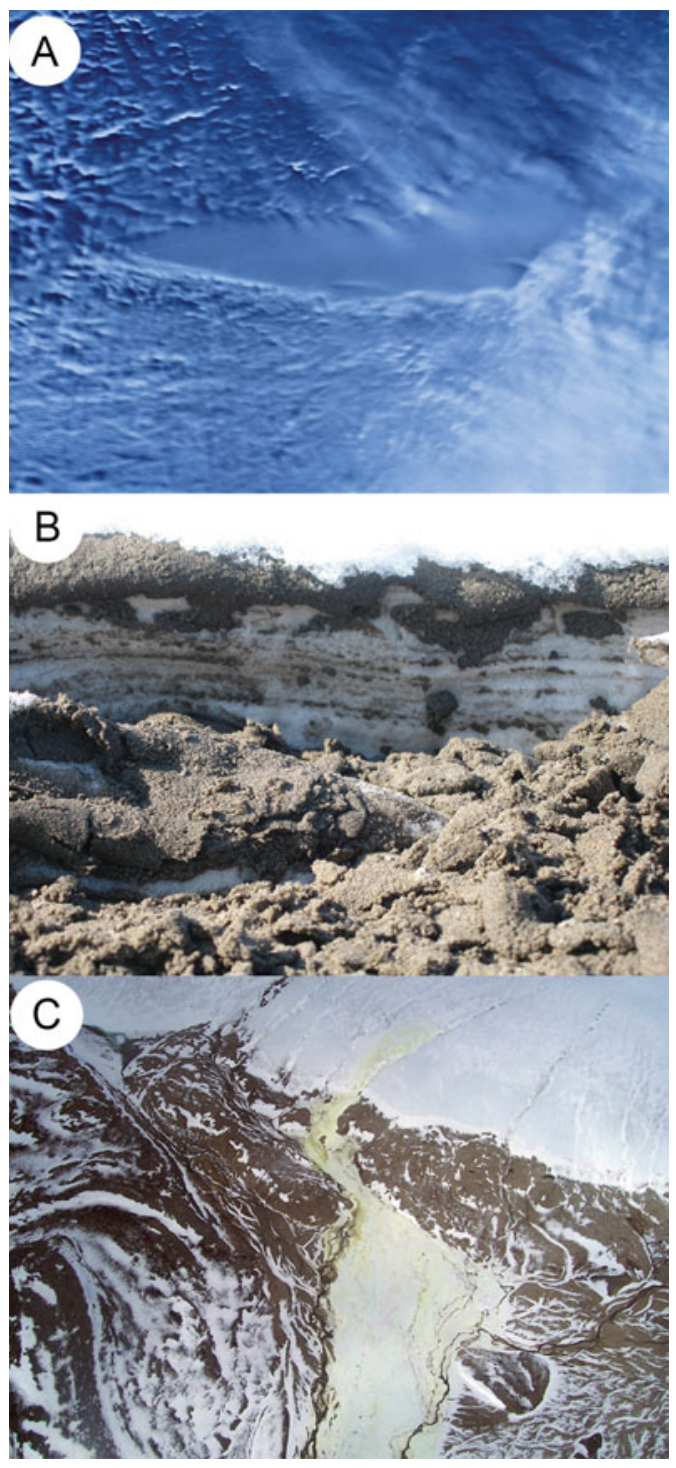

Fig. 6. Europa and Enceladus Surface Ice. (A) Site 20 - Radar image of Lake Vostok, Antarctica (Credit: NASA Goddard). This site can also be used as an analogue for the Brine Ocean and ocean floor environments. (B) Site 21 - Permafrost site from the Canadian Arctic (L.J. Preston). (C) Site 22 - Aerial photograph of sulphur-on-ice deposits, Borup Fiord Pass, Ellesmere Island (Credit: Damhait Gleeson, NASA/JPL).

2003) and the impact on life of the range of salinity, acidity, temperature and pressure conditions that might be found there (see Fig. 7 for potential terrestrial analogue sites).

Finally, a habitable seafloor environment has been postulated for Europa due to extensive evidence from the Earth's subsurface and ocean floor environments; particularly in deep sea hydrothermal vent fields, of vast thriving habitats (Fig. 8). Analogues for these potentially habitable environments are important to consider, even if at present any actual search for them on the moon is restricted to indicators of their activity on the surface and in the near-subsurface. Analogues for all these scenarios, and their potential for habitability, are documented in Table 2.

\section{Enceladus}

Saturn's small moon drew astrobiological interest with the sighting of present-day geological activity occurring at its surface. Jets of fine icy particles and water vapour were observed emerging from the south polar terrain by the Cassini orbiter and are documented by Porco et al. (2006). Dozens of these jets feed into a large plume that reaches several thousand kilometres into space (Porco et al. 2006) and contains water vapour, simple organic compounds and notable levels of volatile species (e.g. $\mathrm{N}_{2}, \mathrm{CO}_{2}, \mathrm{CH}_{4}$ ) (Waite et al. 2006). The south polar terrain surrounding the source regions of the plume was analysed and found to be surprisingly warm (Spencer et al. 2006).

Analysis of icy particles within Enceladus' plume strongly suggest the presence of a subsurface alkaline ocean composed of $\mathrm{NaCl}, \mathrm{NaHCO}_{3}, \mathrm{Na}_{2} \mathrm{CO}_{3}$ and $\mathrm{K}^{+}$(Postberg et al. 2009). Reviews into how this plume might form are provided by Kieffer et al. (2006), Spencer et al. (2006); Castillo-Rogez et al. (2007); Collins \& Goodman (2007); Meyer \& Wisdom (2007); Nimmo et al. (2007) and McKay et al. (2008). Most models regarding the origin of this plume include a subsurface liquid water aquifer, and it is this aquifer, with its potential to support the origin and evolution of life (McKay et al. 2008), that has particular interest for habitability. A plausible subsurface ecosystem on Enceladus would be unlike many terrestrial biomes as they would be independent of $\mathrm{O}_{2}$ and organic materials produced by photosynthesis. Therefore, terrestrial analogues that do not rely on sunlight, oxygen or organics produced at the surface need to be investigated.

Habitable environments and sites where biosignatures of life might be preserved on Enceladus are probably similar to those postulated for Europa and so terrestrial analogues for both have been grouped into Table 2 and show in Figs. 6-8.

\section{Titan}

Titan is the only moon in the Solar system to possess an atmosphere and, also like Earth; the surface is now known to have many dynamic processes. A dense $\mathrm{N}_{2}$-rich atmosphere, evidence of dendritic networks resembling fluvial systems (e.g. Tomasko et al. 2005), as well as lakes and seas (e.g. Stofan et al. 2007; Hayes et al. 2008; Paillou et al. 2008), composed of a mixture of methane and ethane with heavier hydrocarbons, dissolved nitriles and/or atmospheric gases (Flasar 1983; Lunine et al. 1983; Lorenz \& Lunine 2005; Mitri et al. 2007), combined with free $\mathrm{H}_{2}$ near the surface creates a very dynamic environment. If such methane-ethane mixtures are suitable to serve as a biosolvent, then the Titan surface environment might be considered to be habitable, although for exotic life with a very different biochemistry to our own. In addition, Sotin et al. (2005) and Lopes et al. (2007) have inferred the existence of cryovolcanism, and so heating of some of Titan's hydrocarbon reservoirs from below (e.g., Schulze-Makuch \& Grinspoon 2005) would further promote prebiotic organic reactions (Schulze-Makuch et al. 2011) and increases the number of habitable environments. Baross et al. (2007) noted that Titan's environment meets the absolute requirements for life, 


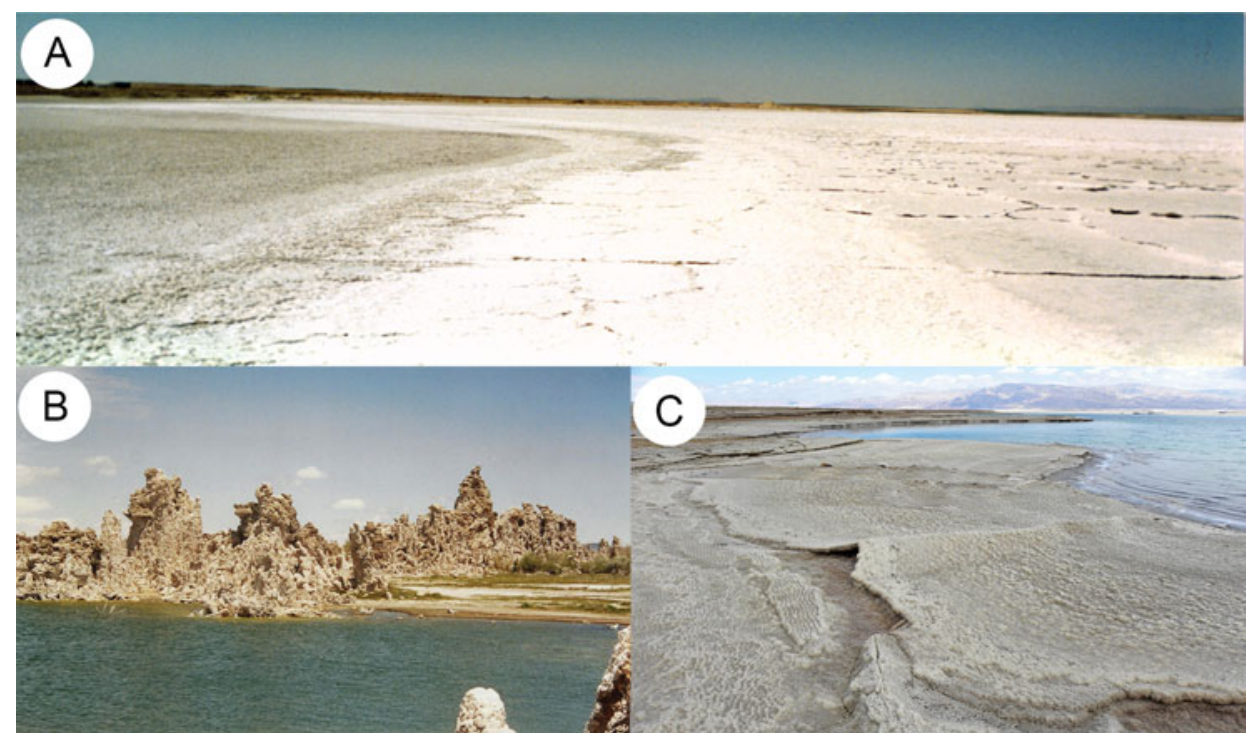

Fig. 7. Europa and Enceladus Brine Ocean. (A) Site 23 - Salt deposits at Lake Tirez, Spain (courtesy of O. Prieto-Ballesteros). (B) Site 25 - The saline soda lake of Mono Lake, California (L.J. Preston). (C) Site 26 - Halite deposits off the western coast of the Dead Sea, Israel (Credit: Wilson44691). Note: No image available for site 24 - The Orca Basin.

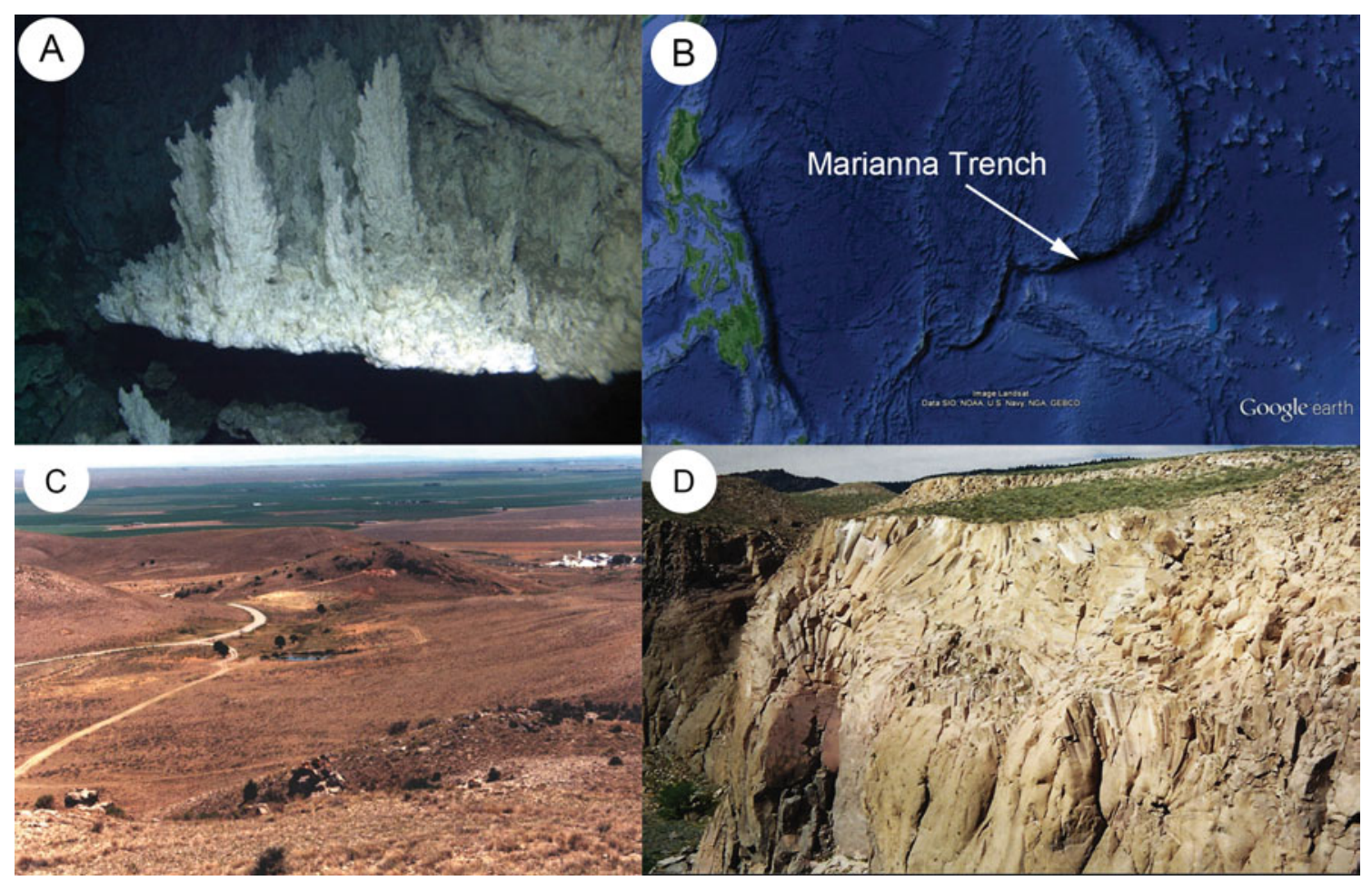

Fig. 8. Europa and Enceladus Ocean Floor. (A) Site 27 - Hydrothermal vent field, Lost City, Mid-Atlantic Ridge (Credit: National Science Foundation (University of Washington/Woods Hole Oceanographic Institution)). (B) Site 28 - Location of the Marianna Trench, Pacific Ocean (Credit: Google Earth 2013). (C) Site 29 - Aerial photograph of the Lidy Hot Springs, USA (courtesy of the USGS). (D) Site 30 - Columnar jointing of the Columbia River Basalts, USA (L.J. Preston).

including thermodynamic disequilibrium, an abundant carbon inventory and a fluid environment.

In addition to the hydrocarbon-drenched surface environment, there is indirect evidence from radar measurements of a deep subsurface ocean (Lorenz et al. 2008), probably composed of a water-ammonia mixture. Such an environment may therefore also be considered habitable for organisms with a polar solvent biochemistry closer to that of terrestrial life. In this way, it is possible that Titan could harbour two biospheres: one on the surface using hydrocarbons as the biosolvent and 


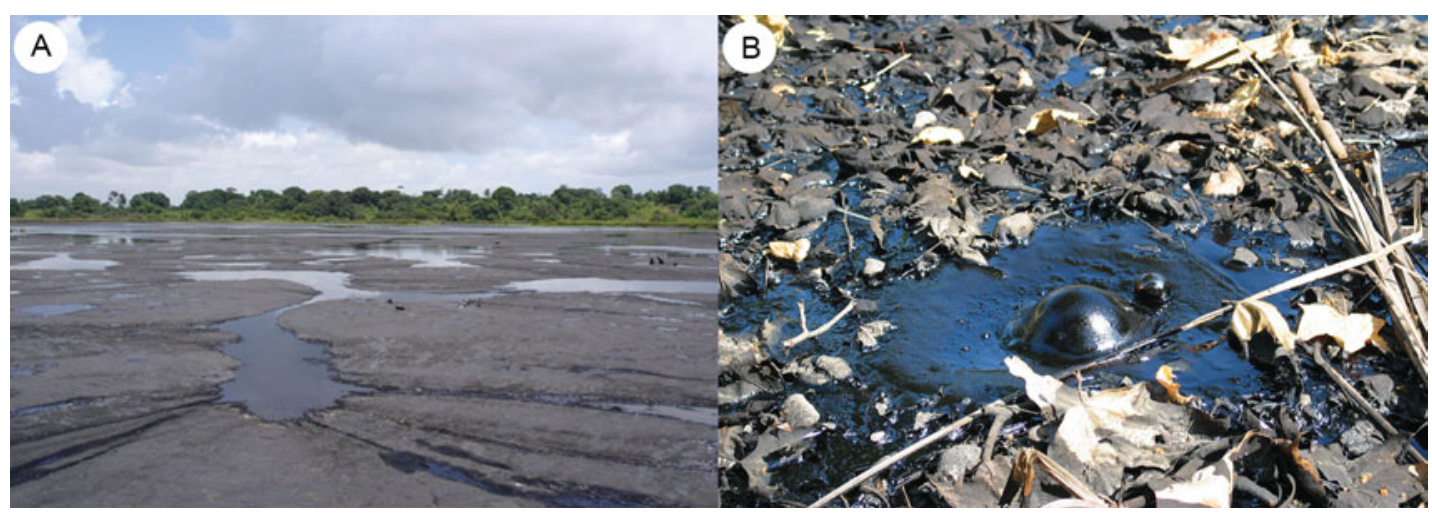

Fig. 9. Titan. (A) Site 31 - Liquid asphalt of Pitch Lake, Trinidad and Tobago (courtesy of D. Schulze-Makuch). (B) Site 32 - Emerging gas bubble at Rancho La Brea Tar Pits, California (Credit: Daniel Schwen).

another, water-based, deep in the interior, but entirely ecologically segregated from each other as they would have to be based on fundamentally different biochemistries. Considering both potential habitats, the range of habitable environments on Titan extends from the moon's surface to a few kilometres depth within the silicate core, which yields a total potential biosphere volume of $\sim 4 \times 10^{10} \mathrm{~km}^{3}$ : more than twice that of the Earth's (Norman \& Fortes 2011).

The environment on Titan is so different to that on Earth, in terms of physical characteristics such as the temperature regime as well as chemical composition of the fluid reservoirs and lack of liquid water and free oxygen, that terrestrial analogue sites are poor matches. Life as we know it may not be found on Titan, but we have not yet been able to rule-out the possibility of viable biochemical systems based on very different solvents, informational storage or structural molecules. Nonetheless, a few terrestrial locales do replicate some features of the Titanic environment (detailed in Table 3 and Fig. 9) and have been used to inform discussion on the habitability of the moon. Additional analogue sites are greatly needed for potential habitable environments on Titan to enable us to better understand the moon and where to send future probes; however, this is a difficult mission. We need to learn more about Titan to recognize the valuable terrestrial analogues, but in the search for habitability, analogues commonly drive our exploration.

\section{Conclusions}

We have collated information on a selection of first, second and third tier analogue sites on Earth to enable the study of potential habitable environments on Venus, Mars, Europa, Enceladus and Titan. Atmospheric habitable zones on Venus are discussed in comparison with high-altitude terrestrial biospheres. The habitability and biosignature preservation potential of 18 analogue sites has been described to address the three climatic and mineralogical eras of Mars. These range from the deserts of the Atacama, to perennial springs in the Canadian High Arctic, and volcanoes in Russia and Africa. A total of 11 analogue sites are reviewed that are helping to predict the habitability potential of the surface ice layers, brine oceans and ocean floors of the moons Europa and Enceladus. Aspects of one analogue site in particular, Lake Vostok and other Antarctic subglacial lakes can be used to represent many aspects of these icy moons. Finally the habitability of Titan, with its extreme environment, can be to some extent investigated using three natural asphalt and petroleum reservoir analogue sites. The terrestrial analogues described in this review have been assigned in Tables $1-3$ to a particular planetary body; however, many have features that are applicable to more than one. This wider applicability is not always apparent from the primary literature, perhaps as authors are focused on one particular target, and so we have made these opportunities clear in this review. Permafrost sites throughout the Earth are good analogues for Europa, Enceladus, Mars and potentially any celestial body that is unable to sustain liquid water on its surface. Other examples include the deep subsurface habitats at Lidy Hot Springs and within the Columbia River Flood Basalts. These are important analogues for potential subsurface habitats on any rocky planetary body, especially Mars and the icy moons.

Aside from the extraterrestrial applicability of a site, we can see from this review that the value of a terrestrial analogue for habitability does not solely rely on the similarity of the analogue to its target, or the level to which we are confident in its fidelity. A much simpler value can be assigned: accessibility. All the analogue sites described in this review are of value, however, only half of them are readily accessible without specialized equipment or excessive financial contributions. It is of no surprise, therefore, that analogue sites most often cited in the literature are those that are easy to get to and can be revisited if needed; are large enough to sustain multiple sampling excursions and teams; and permissions regarding visitation and sampling under most circumstances are obtainable. How many scientifically valuable sites are being understudied or simply overlooked due to a lack of accessibility or available resources?

A large and some would say key, area of research into habitability involves extremophiles and the types of life found in these planetary analogue environments. Habitability does 
not necessitate the presence of life, just the conditions which could allow for it, and although this review is focused on the analogue sites themselves, it has found that more often than not they contain some form of extremophilic life, and may indeed only be an analogue site due to this biota. As such a compilation of the range and diversity of both prokaryotic and eukaryotic extremophilic life would be invaluable to researchers. An extremophile database has been started called ExtremeDB (http://extrem.igib.res.in/) and is explained by Majhi et al. (2013) but is currently early in development focused primarily on prokaryotes. The completion of this database is a huge undertaking and will need support and commitment from the scientific community to make it work.

It goes without saying that this review is not able to document every analogue site that has been used in the past, or is appropriate to be used in the future, for planetary habitability studies. What is required is a repository for this information that is open access, and populated and curated by scientists and specialists working in these areas.

A number of attempts have been made to create an analogue database such as NASA's Analogs Database (http://external. jsc.nasa.gov/analogs/index.cfm) initially compiled to support NASAs Vision for Space Exploration activities. The number of sites currently in the catalogue stands at 37 (only 4 more than this review). However, there are a number of important ways in which this original effort can be improved upon. The NASA Analogs Database provides only scant information on many of the listed sites, there is little critical assessment of the fidelity of the correspondence with extraterrestrial targets, and there is poor global coverage of appropriate analogue sites, the vast majority are based in North America. Furthermore, the site appears to not have been updated since 2011. This discussion is not intended to be critical of the volunteers who created this initial database - it is no small order to set-up then curate and maintain a database such as this - but as a rallying cry for the extremophile and analogue communities as a whole to come together to pool knowledge and effort to generate a resource of great utility for all: a database which is more comprehensively detailed, broader in its geographical coverage, and consistently kept up-to-date.

A 'Catalogue for Planetary Analogues' has been compiled by the CAFE Study (Preston et al. 2012) commissioned by the European Space Agency. This catalogue contains 93 analogue sites from all seven continents and includes information on the geology, biology and chemistry of the sites, accessibility, costs, logistics and previous campaigns. Currently this catalogue only documents analogue sites for Mars and the Moon and is at present not publically available. It was clear during the compilation of this catalogue, and indeed this review, how difficult it is to curate such a huge volume of information, to make sure there is an equal global spread of sites and to gain access to the data. However, a catalogue or database of these analogue sites is greatly needed to share first-hand knowledge of field sites, to reduce accidental duplication of research and to promote greater international cooperation.

\section{Acknowledgements}

The authors would like to thank all individuals, named in the captions for each figure, for their generous contribution of images. LJP is supported by funding from the Science and Technology Facilities Council (STFC) and LRD is supported by a UK Space Agency Aurora Fellowship.

\section{References}

Abe, F., Kato, C. \& Horikoshi, K. (1999). Pressure-regulated metabolism in microorganisms. Trends Microbiol. 7, 447-453.

Abyzov, S.S. (1993). Microorganisms in the Antarctic ice. In Antarctic Microbiology, ed. Friedmann, E.I., pp. 265-295. Wiley-Liss Inc., New York.

Allwood, A.C., Walter, M.R., Kamber, B.S., Marshall, C.P. \& Burch, I.W. (2006). Stromatolite reef from the Early Archaean era of Australia. Nature 441, 714-718.

Amador, E.S., Bandfield, J.L., Kelley, D.S. \& Brazelton, W. (2013). The Lost City hydrothermal field: a spectroscopic and astrobiological Martian analog. In 44th Lunar and Planetary Science Conf. Abstract no. 2742.

Amils, R. et al. (2007). Extreme environments as Mars terrestrial analogs: the Río Tinto case. Planet. Space Sci. 55, 370-381.

Andersen, D.T., Pollard, W.H., McKay, C.P. \& Heldmann, J. (2002). Cold springs in permafrost on Earth and Mars. J. Geophys. Res. 107, 1-7.

Andrews-Hanna, J.C., Phillips, R.J. \& Zuber, M.T. (2007). Meridiani Planum and the global hydrology of Mars. Nature 446, 163-166.

Bains, W. (2004). Many chemistries could be used to build living systems. Astrobiology 4, 137-167.

Baross, J.A., Benner, S.A., Cody, G.D., Copley, S.D., Pace, N.R., Scott, J.H., Shapiro, R., Sogin, M.L., Stein, J.L., Summons, R. \& Szostak, J.W. (2007). Pushing the boundaries of life. In The Limits of Organic Life in Planetary Systems, pp. 29-42. National Academies Press, Washington.

Battler, M.M. et al. (2012). Characterization of the acidic cold seep emplaced jarositic Golden Deposit, NWT, Canada, as an analogue for jarosite deposition on Mars. Icarus 224, 382-398.

Baumstark-Khan, C. \& Facius, R. (2002). Life under conditions of ionizing radiation. In Astrobiology: The Quest for the Conditions of Life, ed. Horneck, G. \& Baumstark-Khan, C., pp. 261-284. Springer, Berlin.

Bibring, J.P. et al. (2006). Global mineralogical and aqueous Mars history derived from OMEGA/Mars Express data. Science 312, 400-404.

Bibring, J.P. et al. (2007). Coupled ferric oxides and sulfates on the martian surface. Science 317, 1206-1210.

Boston, P.J., Ivanov, M.V. \& McKay, C.P. (1992). On the possibility of chemosynthetic ecosystems in subsurface habitats on Mars. Icarus $\mathbf{9 5}$, 300-308.

Bourgeois, O., Dauteuil, O. \& Van Vliet-Lanoe, B. (1998). Pleistocene subglacial volcanism in Iceland: tectonic implications. Earth Planet. Sci. Lett. 164, 165-178.

Bourke, M.C. (2010). Barchan dune asymmetry: observations from Mars and Earth. Icarus 205, 183-197.

Bourke, M.C. \& Goudie, A.S. (2009). Varieties of barchan form in the Namib Desert and on Mars. Aeolian Res. 1, 45-54.

Bourke, M.C., Bullard, J.E. \& Barnouin-Jha, O.S. (2004). Aeolian sediment transport pathways and aerodynamics at troughs on Mars. J. Geophys. Res. 109, E07005, doi: 10.1029/2003JE002155.

Brazelton, W.J., Schrenk, M.O., Kelley, D.S. \& Baross, J.A. (2006). Methane and sulfur metabolizing microbial communities dominate in the Lost City hydrothermal vent ecosystem. Appl. Environ. Microbiol. 72, 6257-6270.

Brown, A.J., Cudahy, T.J. \& Walter, M.R. (2006). Hydrothermal alteration at the Panorama Formation, North Pole Dome, Pilbara Craton, Western Australia. Precambr. Res. 151, 221-223.

Bryant, E. \& Rech, S. (2008). The effect of moisture on soil microbial communities in the Mojave desert. Astrobiology 8, 427. 
Cabrol, N.A. et al. (2007). Life in the Atacama: searching for life with rovers (science overview). J. Geophys. Res. 112, G04S02, doi: 10.1029/ 2006JG000298

Carlson, R.W., Johnson, R.E. \& Anderson, M.S. (1999). Sulfuric acid on Europa and the radiolytic sulfur cycle. Science 286, 97-99.

Castillo-Rogez, J.C., Matson, D.L., Vance, S.D., Davies, A.G. \& Johnson, T.V. (2007). The early history of Enceladus: setting the scene for today's activity [abstract 2265]. In 38th Lunar and Planetary Science Conference, Lunar and Planetary Institute, Houston.

Cavalazzi, B., Barbieri, R. \& Ori, G.G. (2007). Chemosynthetic microbialites in the Devonian carbonate Mounds of Hamar Laghdad (Anti-Atlas, Morocco). Sediment. Geol. 200, 73-88.

Chapelle, F.H., Neill, O.K., Bradley, P.M., Methé, B.A., Ciufo, S.A., Knobel, L.L. \& Lovley, D.R. (2002). A hydrogen-based subsurface microbial community dominated by methanogens. Nature 415, 312-315.

Chapman, M.G., Allen, C.C., Gudmundsson, M.T., Gulick, V.C., Jakobsson, S.P., Lucchita, B.K., Skilling, S.P. \& Waitt, R.B. (2000). Volcanism and ice interactions on Earth and Mars. In Environmental Effects on Volcanic Eruptions, ed. Zimbelman, J.R. \& Gregg, T.K.P., pp. 39-73. Kluwer Academic, New York.

Chyba, C.F. (2000). Energy for microbial life on Europa. Nature 403, 381-382.

Chyba, C.F. \& Hand, K.P. (2001). Life without photosynthesis. Science 292, 2026-2027.

Chyba, C.F. \& Phillips, C.B. (2001). Possible ecosystems and the search for life on Europa. Proc. Natl. Acad. Sci. U.S. A. 98, 801-804.

Cleaves, J.H. II \& Chalmers, J.H. (2004). Extremophiles may be irrelevant to the origin of life. Astrobiology 4, 1-9.

Cockell, C. (1999). Life on Venus. Planet. Space Sci. 47, 1487-1501.

Cockell, C.S. \& Lee, P. (2002). The biology of impact craters: a review. Biol. Rev. 77, 279-310.

Cockell, C.S., Lee, P., Osinski, G., Horneck, G. \& Broady, P. (2002). Impact-induced microbial endolithic habitats. Meteoritics Planet. Sci. 37, 1287-1298

Collins, G.C. \& Goodman, J.C. (2007). Enceladus' south polar sea. Icarus 189, 72-82.

Connon, S.A., Lester, E.D., Shafaat, H.S., Obenhuber, D.C. \& Ponce, A. (2007). Bacterial diversity in hyperarid Atacama Desert soils. J. Geophys. Res. 112, doi: 10.1029/2006JG000311.

Cousins, C.R. \& Crawford, I.A. (2011). Volcano-Ice interaction as a microbial habitat on Earth and Mars. Astrobiology 11, 695-710.

Dartnell, L.R. (2011). Biological constraints on habitability. Astron. Geophys. 52, 1.25-1.28.

Dartnell, L.R., Desorgher, L., Ward, J.M. \& Coates, A.J. (2007). Modelling the surface and subsurface Martian radiation environment: implications for Astrobiology. Geophys. Res. Lett. 34, L02207.

DasSarma, S. (2003). Extreme Halophiles are models for Astrobiology. Microbe 1, 120-126.

Demidov, N.E. \& Gilichinsky, D.A. (2009). Terrestrial permafrost models and analogues of Martian habitats and inhabitants. Soil Biol. 16, 323-341.

Doran, P.T., Berry Lyons, W. \& McKnight, D.M. (2012). Life in Antarctic deserts and other cold dry environments: astrobiological analogs. ed. Doran, P.T., Berry Lyons, W. \& McKnight, D.M., p. 320. Cambridge University Press, Cambridge. ISBN 978-0-521-88919-3.

Duxbury, N.S., Zotikov, I.A., Nealson, K.H., Romanovsky, V.E. \& Carsey, F.D. (2001). A numerical model for an alternative origin of Lake Vostok and its exobiological implications for Mars. J. Geophys. Res. 106, 1453-1462.

Ellis-Evans, J.C. \& Wynn-Williams, D. (1996). A great lake under the ice. Nature 381, 644-646.

Ewing, S.A., Macalady, J.L., Warren-Rhodes, K., McKay, C.P. \& Amundson, R. (2008). Changes in the soil C cycle at the arid-hyperarid transition in the Atacama Desert. J. Geophys. Res. 113, doi: 10.1029/ 2007JG000495.

Fairén, A.G., Dohm, J.M., Baker, V.R., de Pablo, M.A., Ruiz, J., Ferris, J. \& Anderson, R. (2003). Episodic flood inundations of the northern plains of Mars. Icarus 165, 53-67.
Fairén, A.G., Davila, A.F., Lim, D., Bramall, N., Bonaccorsi, R., Zavaleta, J., Uceda, E.R., Stoker, C., Wierzchos, J., Dohm, J.M., Amils, R., Andersen, D. \& McKay, C.P. (2010). Astrobiology through the Ages of Mars: The Study of Terrestrial Analogues to Understand the Habitability of Mars. Astrobiology 10, 821-843.

Fernández-Remolar, D.C., Morris, R.V., Gruener, J.E., Amils, R. \& Knoll, A.H. (2005). The Rio Tinto Basin, Spain: mineralogy, sedimentary geobiology, and implications for interpretation of outcrop rocks at Meridiani Planum, Mars. Earth Planet. Sci. Lett. 240, 149-167.

Flasar, F.M. (1983). Oceans on Titan? Science 221, 55-57.

Friedmann, E.I. (1980). Endolithic microbial life in hot and cold deserts. Orig. Life 10, 223-235.

Gaidos, E.J., Nealson, K.H. \& Kirschvink, J.L. (1999). Life in ice-covered oceans. Science 284, 1631-1633.

Gendrin, A. et al. (2005). Sulfates in martian layered terrains: the OMEGA/Mars Express view. Science 307, 1587-1591.

Gilichinsky, D.A. (2002). Permafrost model of extraterrestrial habitat. In Astrobiology: The Quest for the Conditions of Life, ed. Horneck, G. \& Baumstark-Khan, C., pp. 125-142. Springer, Berlin.

Gilichinsky, D.A., Soina, V.S. \& Petrova, M.A. (1993). Cryoprotective properties of water in the Earth cryolithosphere and its role in exobiology. Orig. Life Evol. Biosph. 2, 65-75.

Gilichinsky, D.A. et al. (2007). Microbial populations in Antarctic permafrost: biodiversity, state, age, and implication for astrobiology. Astrobiology 7, 275-311.

Gleeson, D., Pappalardo, R.T., Grasby, S.E., Anderson, M.S., Beauchamp, B., Castano, R., Chien, S., Doggett, T., Mandrake, L. \& Wagstaff, K. (2010). Characterization of a sulfur-rich Arctic spring site and field analog to Europa using hyperspectral data. Remote Sens. Environ. 114, 1297-1311.

Gleeson, D., Grasby, S., Williamson, C., Spear, J., Pappalardo, R. \& Templeton, A. (2011). Low temperature $\mathrm{S}_{0}$ biomineralization at a supraglacial spring system in the Canadian High Arctic. Geobiology 9 , $360-375$.

Gleeson, D.F., Pappalardo, R.T., Anderson, M.S., Grasby, S.E., Mielke, R.E., Wright, K.E. \& Templeton, A.S. (2012). Biosignature detection at an arctic analog to Europa. Astrobiology 12, 135-150.

Glud, R.N., Wenzhöfer, F., Middelboe, M., Oguri, K., Turnewitsch, R., Canfield, D.E. \& Kitazato, H. (2013). High rates of microbial carbon turnover in sediments in the deepest oceanic trench on Earth. Nature Geosci. 6, 284-288.

Gónzález-Toril, E., Gómez, F., Irazabal, N., Amils, R. \& Marín, I. (1999). Comparative genomic characterization of iron oxidizing bacteria isolated from the Tinto River. In Biohydrometallurgy and the Environment towards the Mining of the 21st century, vol. B. ed. Amils, R., Ballester, A., pp. 149-157. Elsevier, Amsterdam.

Gónzález-Toril, E., Llobet-Brossa, E., Casamayor, E.O., Amann, R. \& Amils, R. (2003). Microbial ecology of an extreme acidic environment, the Tinto River. Appl. Environ. Microbiol. 69, 4853-4865.

Grasby, S.E., Allen, C.C., Longazo, T.G., Lisle, J.T., Griffin, D.W. \& Beauchamp, B. (2003). Supraglacial sulfur springs and associated biological activity in the Canadian High Arctic - signs of life beneath the ice. Astrobiology 3, 583-596.

Greeley, R., Bridges, N.T., Kuzmin, R.O. \& Laity, J.E. (2002). Terrestrial analogs to wind-related features at the Viking and Pathfinder landing sites on Mars. J. Geophys. Res. 107, 5005, doi: 10.1029/2000JE001481.

Grieve, R.A.F. (1988). The Haughton impact structure: summary and synthesis of the results of the HISS project. Meteoritics 23, 249-254.

Gudmundsson, M.T., Sigmundsson, F. \& Björnsson, H. (1997). Ice-volcano interaction of the 1996 Gjalp subglacial eruption, Vatnajökull, Iceland. Nature 389, 954-957.

Harris, M, Wickramasinghe, C., Lloyd, D., Narlikar, J., Rajaratnam, P., Turner, M., Al-Mufti, S., Wallis, M., Ramadurai, S. \& Hoyle, F. (2001). The detection of living cells in stratospheric samples. In Proc. SPIE 4495. Hasimoto, G.L., Roos-Serote, M., Sugita, S., Gilmore, M.S., Kamp, L.W., Carlson, R.W. \& Baines, K.H. (2008). Felsic highland crust on Venus suggested by Galileo Near-Infrared Mapping Spectrometer data. J. Geophys. Res. 113, E00B24, doi: 10.1029/2008JE003134. 
Hauber, E., Mathias Ulrich, Preusker, F., Trauthan, F., Reiss, D., Carlsson, A.E., Hiesinger, H., Jaumann, R., Johansson, H.A.B., Johansson, L., Johnsson, A., McDaniel, S., Olvmo, M. \& Zanetti, M. (2009). Svalbard (Norway) as a terrestrial analogue for Martian landforms: Results on alluvial fans. European Planetary Science Congress Abstracts, vol. 4 EPSC2009-772.

Hayes, A. et al. (2008). Hydrocarbon lakes on Titan: distribution and interaction with a porous regolith. Geophys. Res. Lett. 35, L09204.

Heldmann, J.L., Toon, O.B., Pollard, W.H., Mellon, M.T., McKay, C.P. \& Andersen, D.T. (2000). Cold Springs in Thick, Continuous Permafrost on Earth and Mars. Eos, Trans. AGU 81(48), P61B-05.

Heldmann, J.L., Pollard, W., McKay, C.P., Marinova, M.M., Davila, A., Williams, K.E., Lacelle, D. \& Andersen, D.T. (2013). The high elevation dry valleys in Antarctica as analog sites for subsurface ice on Mars. Planet. Space Sci. http://dx.doi.org/10.1016/j.pss.2013.05.019.

Herrera, A., Cockell, C.S., Self, S., Blaxter, M., Reitner, J., Thorsteinsson, T., Arp, G., Drose, W. \& Tindle, A.G. (2009). A cryptoendolithic community in volcanic glass. Astrobiology 9, 369-381.

Hoover, R.B. \& Gilichinsky, D. (2001). Significance to astrobiology of microorganisms in permafrost and ice. In Permafrost Response on Economic Development, Environmental Security and Natural Resources, ed. Paepe, R. \& Melnikov, V., pp. 553-579. Kluwer Academic Publishers, Dordrecht, The Netherlands.

Horneck, G. (2000). The microbial world and the case for Mars. Planet. Space Sci. 48, 1053-1063.

Jakosky, B.M. \& Shock, E.L. (1998). The biological potential of Mars, the early Earth, and Europa. J. Geophys. Res. 103, 19359-19364.

Jouzel, J., Petit, J.R., Souchez, R., Barkov, N.I., Lipenkov, V. Ya., Raynaud, D., Stievenard, M., Vassiliev, N.I., Verbeke, V. \& Vimeux, F. (1999). More than 200 meters of lake ice above subglacial Lake Vostok, Antarctica. Science 286, 2138-2141.

Kapitsa, A.P., Ridley, J.K., de Robin, G.Q., Siegert, M.J. \& Zotikov, I.A. (1996). A large deep freshwater lake beneath the ice of central East Antarctica. Nature 381, 684-686.

Kargel, J.S., Kaye, J.Z., Head, J.W., Marion, G.M., Sassen, R., Crowley, J.K., Ballesteros, O.P., Grant, S.A. \& Hogenboom, D.L. (2000). Europa's crust and ocean: origin, composition, and the prospects for life. Icarus 148, 226-265.

Karl, D.M., Bird, D.F., Björkman, K., Houlihan, T., Shackelford, R. \& Tupas, L. (1999). Microorganisms in the accreted ice of Lake Vostok, Antarctica. Science 286, 2144-2147.

Kasting, J.F. (1988). Runaway and moist greenhouse atmospheres and the evolution of Earth and Venus. Icarus 74, 472-494.

Kasting, J.F., Whitmire, D.P. \& Reynolds, R.T. (1993). Habitable zones around main sequence stars. Icarus 101, 108-128.

Kato, C., Li, L., Nogi, Y., Nakamura, Y., Tamaoka, J. \& Horikoshi, K. (1998). Extremely barophilic bacteria isolated from the Mariana Trench, Challenger Deep, at a depth of 11000 meters. Appl. Environ. Microbiol. 64, $1510-1513$

Kelley, D.S. et al. (2001). An off-axis hydrothermal vent field discovered near the Mid-Atlantic Ridge at $30^{\circ} \mathrm{N}$. Nature 412, 145-149.

Kelley, D.S. et al. (2005). A serpentinite-hosted ecosystem: the Lost City hydrothermal field. Science 307, 1428-1434.

Kelley, D.S., Früh-Green, G.L., Karson, J.A. \& Ludwig, K.A. (2007). The Lost City hydrothermal field revisited. Oceanography 20, 90-99.

Keszthelyi, L.P. (2011). Europa Awakening. Nature 479, 485.

Kieffer, S.W., Lu, X., Bethke, C.M., Spencer, J.R., Marshak, S. \& Navrotsky, A. (2006). A clathrate reservoir hypothesis for Enceladus' south polar plume. Science 314, 1764-1766.

Kim, J.S. \& Crowley, D.E. (2007). Microbial diversity in natural asphalts of the Rancho La Brea Tar Pits. Appl. Environ. Microbiol. 73, 4579-4591.

Kis-Papo, T., Grishkan, I., Oren, A., Wasser, S.P. \& Nevo, E. (2001). Spatiotemporal diversity of filamentous fungi in the hypersaline Dead Sea. Mycol. Res. 105, 749-756.

Krumgalz, B.S. (1997). Ion interaction approach to geochemical aspects of the Dead Sea. In The Dead Sea, The Lake and Its Setting. ed. Niemi, T.M., Ben-Avraham, Z. \& Gat, J.R., pp. 145-160. Oxford University Press, New York.
Krumgalz, B.S., Hecht, A., Starinsky, A. \& Katz, A. (2000). Thermodynamic constraints on Dead Sea evaporation: can the Dead Sea dry up? Chem. Geol. 165, 1-11.

Kusky, T.M., Li, J.-H. \& Tucker, R.D. (2001). The Archean Dongwanzi Ophiolite Complex, North China Craton: 2.505-Billion-Year-Old Oceanic Crust and Mantle. Science 292, 1142-1145.

Landis, G.A. (2001). Martian water: are there extant halobacteria on Mars? Astrobiology 1, 161-164.

Léveillé, R. (2010). A half-century of terrestrial analog studies: from crater on the Moon to searching for life on Mars. Planet. Space. Sci. 58, 631-638.

L'Haridon, S., Reysenbacht, A.-L., Glénat, P., Prieur, D. \& Jeanthon, C. (1995). Hot subterranean biosphere in a continental oil reservoir. Nature 377, 223-224.

Lopes, R.M.C. et al. (2007). Cryovolcanic features on Titan's surface as revealed by the Cassini Titan Radar Mapper. Icarus 186, 395-412.

Lorenz, R.D. \& Lunine, J.I. (2005). Titan's surface before Cassini. Planet. Space Sci. 53, 557-576.

Lorenz, R.D. et al. (2008). Titan's inventory of organic surface materials. Geophys. Res. Lett. 35, L02206. Doi: 10.1029/2007GL032118.

Lorenz, R.D., Gleeson, D., Prieto-Ballesteros, O., Gomez, F., Hand, K. \& Bulat, S. (2011). Analog environments for a Europa lander mission. $A d v$. Space Res. 48, 689-696.

Lunine, J.I., Stevenson, D.J. \& Yung, Y.L. (1983). Ethane ocean on Titan. Science 222, 1229.

Majhi, M.C., Behera, A.K., Kulshreshtha, N.M., Mahmooduzafar, D., Kumar, R. \& Kumar, A. (2013). ExtremeDB: a unified web repository of extremophilic archaea and bacteria. PLOS ONE 8, e63083.

Malin, M.C. \& Edgett, K.S. (2000). Evidence for recent groundwater seepage and surface runoff on Mars. Science 288, 2330-2335.

Marion, G.M., Fritsen, C.H., Eicken, H. \& Payne, M.C. (2003). The search for life on Europa: limiting environmental factors, potential habitats, and Earth analogues. Astrobiology 3, 785-811.

Mayer, D.P., Arvidson, R.E., Wang, A., Sobron, P. \& Zheng, M.P. (2009). Mapping minerals at a potential Mars analog site on the Tibetan Plateau. In 40th Lunar and Planetary Science Conf. Abstract no. 1877.

McCollom, T.M. (1999). Methanogenesis as a potential source of chemical energy for primary biomass production by autotrophic organisms in hydrothermal systems on Europa. J. Geophys. Res. 104, doi: 10.1029/ 1999JE001126.

McCord, T.B. et al. (1999). Hydrated salt minerals on Europa's surface from the Galileo near-infrared mapping spectrometer (NIMS) investigation. J. Geophys. Res. Planets 104, 11827-11851.

McEwen, A.S. et al. (2007). A closer look at water-related geologic activity on Mars. Science 317, 1706-1709.

McKay, C.P., Porco, C.C., Altheide, T., Davis, W.L. \& Kral, T.A. (2008). The possible origin and persistence of life on Enceladus and detection of biomarkers in the Plume. Astrobiology 8, 909-919.

Meckler, A.N., Schubert, C.J., Hochuli, P.A., Plessen, B., Birgel, D., Flower, B.P., Hinrichs, K.-U. \& Huag, G.H. (2008). Glacial to Holocene terrigenous organic matter input to sediments from Orca Basin, Gulf of Mexico - a combined optical and biomarker approach. Earth Planet. Sci. Lett. 272, 251-263.

Meyer, J. \& Wisdom, J. (2007). Tidal heating in Enceladus. Icarus 188, 535-539.

Michel, F.A. (1977). Hydrogeologic studies of springs in the Central Mackenzie Valley, North West Territories, Canada. M.Sc. thesis, University of Waterloo, Waterloo, Ontario.

Miteva, V.I., Sheridan, P.P. \& Brenchley, J.E. (2004). Phylogenetic and physiological diversity of microorganisms isolated from a deep Greenland glacier ice core. Appl. Environ. Microbiol. 70, 202-213.

Mitri, G., Showman, A.P., Lunine, J.I. \& Lorenz, R.D. (2007). Hydrocarbon lakes on Titan. Icarus 186, 385-394.

Nadis, S. (1999). Moves are afoot to probe the lake trapped beneath Antarctic ice. Nature 401, 203.

Navarro-Gonzalez, R., Montoya, L., Davis, W. \& McKay, C. (2002). Laboratory support for a methanogensis driven biosphere in Europa. In Europa Focus Group Workshop 3, ed. Greeley, R., p. 35. Arizona State University, Tempe. 
Navarro-González, R. et al. (2003). Mars-like soils in the Atacama desert, Chile, and the dry limit of microbial life. Science 302, 1018-1021.

Nimmo, F., Spencer, J.R., Pappalardo, R.T. \& Mullen, M.E. (2007). Shear heating as the origin of the plumes and heat flux on Enceladus. Nature 447, 289-291.

Norman, L.H. \& Fortes, D.A. (2011). Is there life on...Titan? Astron. Geophys. 52, 1.39-1.42.

Onofri, S., Selbmann, L., Zucconi, L. \& Pagano, S. (2004). Antarctic microfungi as models for exobiology. Planet. Space Sci. 52, 229-237.

Osinski, G.R. \& Lee, P. (2005). Intra-crater sedimentary deposits at the Haughton impact structure, Devon Island, Canadian High Arctic. Meteoritics Planet. Sci. 40, 1887-1899.

Osinski, G.R., Spray, J.G. \& Lee, P. (2001). Impact-induced hydrothermal activity within the Haughton impact structure, Arctic Canada: generation or a transient, warm, wet oasis. Meteoritics Planet. Sci. 36, 731-745.

Osinski, G.R., Lee, P., Spray, J. G., Parnell, J., Lim, D.S.S., Bunch, T.E., Cockell, C.S. \& Glass, B. (2005). Geological overview and cratering model of the Haughton impact structure, Devon Island, Canadian High Arctic. Meteoritics Planet. Sci. 40, 1759-1776.

Paillou, P., Lunine, J., Ruffie, G., Encrenaz, P., Wall, S., Lorenz, R. \& Janssen, M. (2008). Microwave dielectric constant of Titan - relevant materials. Geophys. Res. Lett. 35, L18202.

Pappalardo, R.T. (2010). Seeking Europa's ocean. Proc. Int. Astron. Union 6, 101-114.

Parenteau, M.N. \& Cady, S.L. (2010). Microbial biosignatures in ironmineralized phototrophic mats at Chocolate Pots Hot Springs, Yellowstone National Park, United States. Palaios 25, 97-111.

Parnell, J., Lee, P., Cockell, C.S. \& Osinski, G.R. (2004). Microbial colonization in impact-generated hydrothermal sulphate deposits, Haughton impact structure, and implications for sulphates on Mars. Int. J. Astrobiol. 0, 1-10.

Perreault, N.N., Andersen, D.T., Pollard, W.H., Greer, C.W. \& Whyte, L.G. (2007). Characterization of the prokaryotic diversity in cold saline perennial springs in the Canadian high Arctic. Appl. Environ. Microbiol. 73, 1532-1543.

Perreault, N.N., Greer, C.W., Anderson, D.T., Tille, S., LacrampeCouloume, G., Sherwood Lollar, B. \& Whyte, L.G. (2008). Heterotrophic and autotrophic microbial populations in cold perennial springs of the High Arctic. Appl. Environ. Microbiol. 74, 6898-6907.

Perry, R.S., Engel, M.H., Botta, O. \& Staley, J.T. (2003). Amino acid analyses of desert varnish from the Sonoran and Mojave Deserts. Geomicrobiol. J. 20, 427-438.

Perry, R.S., Lynne, B.Y., Sephton, M.A., Kolb, V.M., Perry, C.C. \& Staley, J.T. (2006). Baking black opal in the desert sun: the importance of silica in desert varnish. Geology 34, 537-540.

Pierazzo, E. \& Chyba, C.F. (2002). Cometary delivery of biogenic elements to Europa. Icarus 157, 120-127.

Pikuta, E.V., Detkova, E.N., Bej, A.K., Marsic, D. \& Hoover, R.B. (2003). Anaerobic halo-alkaliphilic bacterial community of athalassic, hypersaline Mono Lake and Owens Lake in California. In Instruments, Methods, and Missions for Astrobiology, ed. Hoover, R.B., Rozanov, A.Y. \& Paepe, R.R., pp. 130-144. Proc. SPIE 4859. The International Society for Optical Engineering, Bellingham, WA: SPIE.

Pilcher, R.S. \& Blumstein, R.D. (2007). Brine volume and salt dissolution rates in Orca Basin, northeast Gulf of Mexico. AAPG Bull. 91, 823-833.

Pollard, W., Haltigin, T., Whyte, L., Niederberger, T., Anderson, D., Omelon, C., Nadeau, J., Ecclestone, M. \& Lebeuf, M. (2009). Overview of analogue science activities at the McGill Arctic Research Station, Axel Heiberg Island, Canadian High Arctic. Planet. Space Sci. 57, 646-659.

Pollard, W.H., Omelon, C., Andersen, D.T. \& McKay, C.P. (1999). Perennial spring occurrence in the Expedition Fiord area of Western Axel Heiberg Island, Canadian High Arctic. Can. J. Earth Sci. 36, 105-120.

Ponce, A., Anderson, R.C. \& McKay, C.P. (2011a). Microbial habitability in Periglacial Soils of Kilimanjaro. In Analogue Sites for Mars Missions. Abstract no. 6018 .
Ponce, A. et al. (2011b). Microbial Diversity of Kilimanjaro's Northern Ice Field.

Porco, C.C. et al. (2006). Cassini observes the active south pole of Enceladus. Science 311, 1393-1401.

Postberg, F., Kempf, S., Schmidt, J., Brilliantov, N., Beinsen, A., Abel, B., Buck, U. \& Srama, R. (2009). Sodium salts in E-ring ice grains from an ocean below the surface of Enceladus. Nature 459, 1098-1101.

Preston, L.J., Benedix, G.K., Genge, M.J. \& Sephton, M.A. (2008). A multidisciplinary study of silica sinter deposits with applications to silica identification and detection of fossil life on Mars. Icarus 198, $331-350$.

Preston, L.J., Shuster, J., Fernández-Remolar, D., Banerjee, N.R., Osinski, G.R. \& Southam, G. (2011). The preservation and degradation of filamentous bacteria and biomolecules in iron oxide deposits from Rio Tinto, Spain. Geobiology 9, 233-249.

Preston, L.J., Barber, S.J., Grady, M.M. \& the CAFE Team. (2012). Introducing a new on-line resource for planning scientific field investigations in planetary analogue environments: CAFE. In Astrobiology Science Conf., Atlanta, Georgia, April 2012. (Abstract \# 1350083).

Price, P.B. (2000). A habitat for psychrophiles in deep Antarctic ice. Proc. Natl. Acad. Sci. USA 97, 1247-1251.

Prieto-Ballesteros, O., Rodríguez, N., Kargel, J.S., González Kessler, C., Amils, R. \& Fernández-Remolar, D. (2003). Tírez Lake as a terrestrial analog of Europa. Astrobiology 3, 863-877.

Priscu, J.C. et al. (1999). Geomicrobiology of subglacial ice above Lake Vostok, Antarctica. Science 286, 2141-2144.

Psenner, R. (1999). Living in a dusty world: airborne dust as a key factor for alpine lakes. Water Air Soil Pollut. 112, 217-227.

Reynolds, R.T., Squyres, S.W., Colburn, D.S. \& McKay, C.P. (1983). On the habitability of Europa. Icarus 56, 246-254.

Rivkina, E.M., Friedmann, E.I., McKay, C.P. \& Gilichinsky, D.A. (2000). Metabolic activity of permafrost bacteria below the freezing point. Appl. Environ. Microbiol. 66, 3230-3233.

Roberts, J.H. \& Nimmo, F. (2008). Tidal heating and the long-term stability of a subsurface ocean on Enceladus. Icarus 194, 675-689.

Rothschild, L.J. \& Mancinelli, R.L. (2001). Life in extreme environments. Nature 409, 1092-1101.

Ruff, S.W. et al. (2011). Characteristics, distribution, origin, and significance of opaline silica observed by the Spirit rover in Gusev crater, Mars. $J$. Geophys. Res. 116, Doi: 10.1029/2010JE003767.

Sattler, B., Puxbaum, H. \& Psenner, R. (2001). Bacterial growth in supercooled cloud droplets. Geophys. Res. Lett. 28, 239-242.

Schulze-Makuch, D. \& Grinspoon, D.H. (2005). Biologically enhanced energy and carbon cycling on Titan? Astrobiology 5, 560-567.

Schulze-Makuch, D. \& Irwin, L.N. (2002). Energy cycling and hypothetical organisms in Europa's ocean. Astrobiology 2, 105-121.

Schulze-Makuch, D., Grinspoon, D., Abbas, O., Irwin, L. \& Bullock, M. (2004). A sulfur-based survival strategy for putative phototrophic life in the Venusian atmosphere. Astrobiology 4, 11-18.

Schulze-Makuch, D., Dohm, J.M., Fairén, A.G., Baker, V.R., Fink, W. \& Strom, R.G. (2005). Venus, Mars, and the Ices on Mercury and the Moon: astrobiological implications and proposed mission designs. Astrobiology $\mathbf{5}$, 778-795.

Schulze-Makuch, D. et al. (2011). Microbial life in a liquid Asphalt desert. Astrobiology 11, 241-258.

Segerer, A., Neuner, A., Kristjansson, J.K. \& Stetter, K.O. (1986). Acidianus infernus gen. nov., sp. nov., and Acidianus brierleyi Comb. nov.: facultatively aerobic, extremely acidophilic thermophilic sulfurmetabolizing archaebacteria. Int. J. System. Bacteriol. 36, 559-564.

Shah, S.R., Joye, S.B., Brandes, J.A. \& McNichol, A.P. (2013). Carbon isotopic evidence for microbial control of carbon supply to orca Basin at the seawater-brine interface. Biogeosciences 10, 3175-3183.

Sharma, A., Scott, J.H., Cody, G.D., Fogel, M.L., Hazen, R.M., Hemley, R.J. \& Huntress, W.T. (2002). Microbial activity at gigapascal pressures. Science 295, 1514-1516.

Smith, D.J., Griffin, D.W. \& Schuerger, A.C. (2010). Stratospheric microbiology at $20 \mathrm{~km}$ over the Pacific Ocean. Aerobiologia 26, 35-46. 
Soare, R., Pollard, W. \& Green, D. (2001). Deductive model proposed for evaluating terrestrial analogues. EOS 82, 501.

Soina, V.S., Vorobiova, E.A., Zvyagintsev, D.G. \& Gilichinsky, D.A. (1995). Preservation of cell structures in permafrost: a model for exobiology. $A d v$. Space Res. 15, 237-242.

Sotin, C., Head, J.W. III, Tobie, G. (2002). Europa: tidal heating of upwelling thermal plumes and the origin of lenticulae and chaos melting. Geophys. Res. Lett. 29, doi: 10.1029/2001GL013844.

Sotin, C. et al. (2005). Release of volatiles from a possible cryovolcano from near-infrared imaging of Titan. Nature 435, 786-789.

Souness, C.J. \& Abramov, A. (2012). The Volcanic terrains of Kamchatka, Eastern Russia: a Glacial and periglacial environment with potential for Mars analog-based research. In 42nd LPSC, Abstract \# 1071.

Spencer, J.R., Tamppari, L.K., Martin, T.Z. \& Travis, L.D. (1999). Temperatures on Europa from Galileo photopolarimeter - radiometer: night time thermal anomalies. Science 284, 1514-1516.

Spencer, J.R., Pearl, J.C., Segura, M., Flasar, F.M., Mamoutkine, A., Romani, P., Buratti, B.J., Hendrix, A.R., Spilker, L.J. \& Lopes, R.M.C. (2006). Cassini encounters Enceladus: background and the discovery of a south polar hot spot. Science 311, 1401-1405.

Steele, A., Amundsen, H.E.F., Botta, O. \& the AMASE 2006 Team. (2006). The Arctic Mars Analogue Svalbard Expedition 2006. In Proc. Mars 2030 Workshop, pp. 55-60.

Steele, A., Fries, M.D., Amundsen, H.E.F., Mysen, B.O., Fogel, M.L., Schweizer, M. \& Boctor, N.Z. (2007). Comprehensive imaging and Raman spectroscopy of carbonate globules from Martian meteorite ALH 84001 and a terrestrial analogue from Svalbard. Meteoritics Planet. Sci. 42, 1549-1566.

Steele, A., Amundsen, H.E.F., Conrad, P.G., Benning, L. \& Fogel, M. on Behalf of the AMASE 07 team. (2008). Arctic Mars Analogue Svalbard Expedition (AMASE) 2007. In LPSC XXXIX, abstract \#2368.

Stevens, T.O. \& McKinley, J.P. (1995). Lithoautotrophic microbial ecosystems in deep basalt aquifers. Science 270, 450-454.

Stofan, E.R. et al. (2007). The lakes of Titan. Nature 445, 61-64.

Stone, R. (1999). Permafrost comes alive for Siberian researchers. Science 286, 36-37.

Storrie-Lombardi, M.C. \& Sattler, B. (2009). Laser induced fluorescence emission (L.I.F.E.): detection of microbial life in the Ice covers of Antarctic lakes. Astrobiology 9, 659-672.

Sugden, D.E., Marchant, D.R., Potter, N. Jr., Souchez, R.A., Denton, G.H., Swisher, C.G. III \& Tison, J.-L. (1995). Preservation of Miocene glacier ice in East Antarctica. Nature 376, 412-414.

Temkiv, T., Finster, K., Hansen, B., Nielsen, N. \& Karlson, U. (2012). The microbial diversity of a storm cloud as assessed by hailstones. FEMS Microbiol. Ecol. 81, 684-695.

Tierney, T. (1997). Geology of the Mono Basin. Kutsavi Press, Mono Lake Committee, Lee Vining, California, pp. 1-73.

Tomasko, M.G. et al. (2005). Rain, wind and haze during the Huygens probe's decent to Titan's surface. Nature 438, 765-778.
Valdivia-Silva, J.E., Navarro-González, R., Ortega-Gutierrez, F., Fletcher, L.E., Perez-Montaño, S., Condori-Apaza, R. \& McKay, C.P. (2011). Multidisciplinary approach of the hyperarid desert of Pampas de La Joya in southern Peru as a new Mars-like soil analog. Geochim. Cosmochim. Acta 75, 1975-1991.

Valdivia-Silva, J.E., Navarro-González, R., de la Rosa, J. \& McKay, C.P. (2012). Decomposition of sodium formate and L- and D-alanine in the Pampas de la Joya soils: implications as a new geochemical analogue to Martian regolith. Adv. Space Res. 49, 821-833.

Van Kranendonk, M.J., Philippot, P., Lepot, K., Bodorkos, S. \& Pirajno, F. (2008). Geological setting of Earth's oldest fossils in the ca. 3.5 Ga Dresser Formation, Pilbara Craton, Western Australia. Precambr. Res. 167, 93124.

Ventosa, A., Arahal, D.R. \& Volcani, B.E. (1999). Studies on the microbiota of the Dead Sea - 50 years later. In Microbiology and Biogeochemistry of Hypersaline Environments, ed. Oren, A., pp. 139-147. CRC Press, Boca Raton, FL.

Vincent, W.F. (1999). Icy life on a hidden lake. Science 286, 2094-2095.

Wainwright, M., Wickramasinghe, N.C., Narlikar, J.V. \& Rajaratnam, P. (2003). Microorganisms cultured from stratospheric air samples obtained at $41 \mathrm{~km}$. FEMS Microbiol. Lett. 218, 161-165.

Waite, J.H. Jr. et al. (2006). Cassini ion and neutral Mass spectrometer: Enceladus plume composition and structure. Science 311, 1419-1422.

Walker, J.C.G. (1975). Evolution of the atmosphere of Venus. J. Atmos. Sci. 32, 1248-1256.

Walter, M.R., Buick, R. \& Dunlop, J.S.R. (1980). Stromatolites 3400-3500 Myr old from the North Pole area, Western Australia. Nature 284, 443-445.

Wang, A., Zheng, M., Kong, F., Sobron, P. \& Mayer, D.P. (2010). Saline Playas on Qinghai-Tibet Plateau as Mars Analog for the formationpreservation of hydrous salts and biosignatures. In American Geophysical Union, Fall Meeting Abstract\# P12A-02.

Warren-Rhodes, K.A., Rhodes, K., Pointing, S., Ewing, S., Lacap, D., Gómez-Silva, B., Amundson, R., Friedmann, E.I. \& McKay, C.P. (2006). Hypolithic cyanobacteria, dry limit of photosynthesis and microbial ecology in the hyperarid Atacama Desert. Microb. Ecol. 52, 389-398.

Westall, F. (2008). Morphological biosignatures in early terrestrial and extraterrestrial materials. Space Sci. Rev. 135, 95-114.

Wierzchos, J., Ascaso, C. \& McKay, C.P. (2006). Endolithic cyanobacteria in halite rocks from the hyperarid core of the Atacama Desert. Astrobiology 6 , 415-422.

Womack, A., Bohannan, B. \& Green, J. (2010). Biodiversity and biogeography of the atmosphere. Phil. Trans. R. Soc. B: Biol. Sci. 365, 3645-3653.

Wyn-Williams, D.D. \& Edwards, H.G.M. (2000). Antarctic ecosystems as models for extraterrestrial surface habitats. Planet. Space Sci. 48, 10651075.

Yayanos, A.A. (1995). Microbiology to 10500 meters in the deep sea. Annu. Rev. Microbiol. 49, 777-805. 